NBER WORKING PAPER SERIES

\title{
ARE RECESSIONS GOOD FOR YOUR HEALTH BEHAVIORS? IMPACTS OF THE ECONOMIC CRISIS IN ICELAND
}

\author{
Tinna Laufey Ásgeirsdóttir \\ Hope Corman \\ Kelly Noonan \\ Pórhildur Ólafsdóttir \\ Nancy E. Reichman \\ Working Paper 18233 \\ http://www.nber.org/papers/w18233 \\ NATIONAL BUREAU OF ECONOMIC RESEARCH \\ 1050 Massachusetts Avenue \\ Cambridge, MA 02138 \\ July 2012
}

The authors are grateful to the University of Iceland Research Fund, The Icelandic Research Fund, the Edda Center of Excellence, and Princeton University's Center for Health and Wellbeing for financial support; to David Bishai, Dhaval Dave, Partha Deb, Michael Grossman, Ruoding Tan, and the participants of the NBER Spring 2012 Health Economics Workshop for helpful comments; and to Taána, epková, Oliver Joszt, and Norma Lamo for excellent research assistance. The views expressed herein are those of the authors and do not necessarily reflect the views of the National Bureau of Economic Research.

NBER working papers are circulated for discussion and comment purposes. They have not been peerreviewed or been subject to the review by the NBER Board of Directors that accompanies official NBER publications.

(C) 2012 by Tinna Laufey Ásgeirsdóttir, Hope Corman, Kelly Noonan, Pórhildur Ólafsdóttir, and Nancy E. Reichman. All rights reserved. Short sections of text, not to exceed two paragraphs, may be quoted without explicit permission provided that full credit, including (C) notice, is given to the source. 
Are Recessions Good for Your Health Behaviors? Impacts of the Economic Crisis in Iceland Tinna Laufey Ásgeirsdóttir, Hope Corman, Kelly Noonan, Pórhildur Ólafsdóttir, and Nancy E. Reichman NBER Working Paper No. 18233

July 2012

JEL No. I1

\begin{abstract}
$\underline{\text { ABSTRACT }}$
This study exploits the October 2008 economic crisis in Iceland to identify the effects of a macroeconomic downturn on a range of health behaviors. Using longitudinal survey data that include pre- and postreports from the same individuals, we investigate the effects of the crisis on smoking, heavy drinking, dietary behaviors, sleep, and other health behaviors and investigate changes in work hours, real income, wealth, and mental health as potential mediators. We also consider the role of prices in shaping health behaviors and compute participation elasticities for the various behaviors. We find that the crisis led to reductions in all health-compromising behaviors examined and that it led to reductions in certain health-promoting behaviors but increases in others. The individual-level mediators explained some, but not all of the effects. We infer that price increases played a large role in the effects of the crisis on health behaviors.
\end{abstract}

Tinna Laufey Ásgeirsdóttir

University of Iceland

Department of Economics

Oddi v. Sturlugotu

101 Reykjavik

Iceland

ta@hi.is

Hope Corman

Rider University

Department of Economics

2083 Lawrenceville Road

Lawrenceville, NJ 08648

and NBER

corman@rider.edu

Kelly Noonan

Department of Economics

Rider University

2083 Lawrence Road, Room SWG 306

Lawrenceville, NJ 08648

and NBER

knoonan@rider.edu
Pórhildur Ólafsdóttir

University of Iceland

Department of Economics

Oddi v. Sturlugotu

101 Reykjavik

Iceland

Tho32@hi.is

Nancy E. Reichman

Robert Wood Johnson Medical School

Department of Pediatrics

Child Health Institute of New Jersey

89 French St., Room 1348

New Brunswick, NJ 08903

reichmne@umdnj.edu 


\section{Introduction}

The seemingly flourishing economy of Iceland suffered a major meltdown during the first days of October 2008, when the three largest banks collapsed and became nationalized. In a widely-viewed televised address, Prime Minister Geir Haarde announced to the country: "(T)here is a very real danger, fellow citizens, that the Icelandic economy, in the worst case, could be sucked with the banks into the whirlpool and the result could be national bankruptcy" (Prime Minister's Office, 2008). The day of this landmark speech, October 6, 2008, has widely been viewed as the beginning of the economic crisis in Iceland. A period of economic and political turmoil followed, leading to uncertainty about the future prospects of the nation. During the following months, hundreds of firms in the country declared bankruptcy. Inhabitants of Iceland, a population of 320,000 , who weeks earlier thought they were living in one of the world's richest countries, were now facing the prospects of unemployment as well as mounting private and national debt. The announcement of the crisis triggered further unforeseen consequences, including a decision by the United Kingdom to invoke anti-terrorism legislation to freeze the assets of one of the three large banks (Landsbanki), emergency funding from the International Monetary Fund, massive protests against the government, and political instability resulting in a cabinet change in February 2009. A sudden and dramatic macroeconomic shock of this magnitude and scope affects the entire population, particularly in a small open economy with its own currency and for which exchange rates and prices were suddenly and dramatically altered. Such a shock has the potential to affect multiple domains of wellbeing - financial, psychological, and physical.

A growing literature has focused on the effects of macroeconomic conditions on health in developed countries. Pioneering work by Ruhm (2000) found that although there is considerable 
evidence that long-term economic growth promotes population health, short-term downturns in economic activity in the United States counter-intuitively lead to reduced mortality rates. That research has spawned a wave of studies investigating the relationships between business cycles and health that has no doubt been fueled in recent years by the Great Recession in the U.S. and more general global economic decline. Ruhm (2003) found that (1) individuals are less healthy during economic expansions, with the strongest negative effects for those who are of working age, employed, and male; (2) the negative health effects of economic expansions persist or accumulate over time, are larger for acute than chronic ailments, and occur despite a protective effect of income and a possible increase in the use of medical care; and (3) mental health appears to be better during expansions, a pattern opposite from that for physical health.

Economic theory and past research point to several mechanisms by which recessions could affect health. At the macro level, recessions could affect health through changes in physical, public service, or social environments. Recessions could enhance health by leading to reductions in air pollution or traffic or increases in social cohesion in times of crisis, but also could compromise health by leading to deteriorations in public service infrastructure (e.g., reductions in health services or essential services such as police and firefighting) or limiting social opportunities due to reductions in facilities or widespread inability of others to afford them. At the micro level, recessions could affect health through changes in health behaviors (as a response to changes in prices, income, and time constraints, or a result of changes in environmental factors, such as availability of high-quality health care), exposures to health risks (e.g., a construction worker who becomes unemployed may no longer be working with dangerous machinery), or stress resulting from losing a job, income, and/or wealth. The directional effects for changes in exposures to health risks and stress are clear. For health 
behaviors, the focus of this paper, the directional effects would depend on the specific behaviors and pathways.

In considering the effects of macroeconomic fluctuations on health behaviors, studies have generally focused on both health-compromising behaviors, such as binge drinking and smoking. Many fewer have focused on health-promoting behaviors, such as exercise. Although the body of research findings is growing, it is not yet clear whether and how various behaviors are affected. Pacula (2011), in a recent review of the literature on the effects of business cycles on excess alcohol consumption, highlights the empirical challenges involved in isolating business cycle effects from other confounding factors.

In this study, we exploit the October 2008 economic crisis in Iceland-a severe and unexpected macroeconomic shock that can be pinpointed to a single day - to identify the effects of a macroeconomic downturn on a range of individual health behaviors. We use longitudinal survey data collected in 2007 (during the boom) and 2009 (during the bust) that includes pre- and post- reports of the same health behaviors as well as other relevant variables. We investigate the effects of the crisis on a range of health-compromising behaviors (smoking; heavy drinking; consumption of sugared soft drinks, sweets, and fast food; and indoor tanning) and healthpromoting behaviors (consumption of fruits, vegetables, and fish oil; use of dietary supplements; and getting the recommended amount of sleep). We estimate effects for the overall adult population and separately for the working-age population, men, and women.

Across the various health behaviors, the effects of the crisis will depend on the "goods" versus time costs of those behaviors, realized changes in income and time constraints, and crisisinduced changes in relative prices. Overall, we expect that the crisis reduced health behaviors that are goods intensive, such as cigarette smoking, alcohol consumption or taking dietary 
supplements; increased health behaviors that are time intensive, such as getting the recommended amount of sleep; and reduced health behaviors with higher relative price increases (e.g., heavily imported goods such as alcohol or fruit, since a major effect of the crisis was the devaluation of the Icelandic krona).

Because we observe information on health behaviors as well as key hypothesized mechanisms (work hours, real income, wealth, and mental health) on the same individuals over time, we are able to investigate mechanisms underlying changes in health behaviors. We are thus able to disentangle — at least to some extent_-general effects of the economic downturn overall from those arising from individuals' changes in circumstances that resulted from the shock. In this vein, we infer the role of prices in shaping health behaviors and compute participation elasticities for the various behaviors.

\section{Background}

\section{Empirical literature}

The most studied health behaviors as outcomes of macroeconomic fluctuations are alcohol use and abuse. ${ }^{1}$ Findings on the effects of the business cycle on problem or binge drinking remain mixed. For example, three studies using data from the U.S. Behavioral Risk Factor Surveillance System (BRFSS) survey to examine the impact of poor economic conditions on problem drinking have arrived at very different conclusions. ${ }^{2}$ Ruhm and Black (2002) concluded that problem drinking decreases during recessions, while Dee (2001) concluded that problem drinking is countercyclical (that is, people drink too much in hard economic times) and Vilaplana, Labeaga and Jiménez-Martín (2006) concluded that drinking is unaffected by the

\footnotetext{
${ }^{1}$ Although light or moderate alcohol use is not necessarily a health-compromising behavior, some studies use overall consumption as a proxy for problem drinking.

${ }^{2}$ These papers serve as examples. See Pacula (2011) and Xu and Kaestner (2010) for more extensive literature reviews.
} 
business cycle. According to Pacula (2011), the discrepancies across studies arise from the use of different empirical specifications, measures of key variables, and choice of control variables. A more recent study by Davalos, Fang and French (2011), using the National Epidemiological Survey on Alcohol and Related Conditions, found results consistent with those of Dee- that increases in unemployment rates are positively related to binge drinking. Xu and Kaestner (2010) expanded on this line of research in a study of the effects of employment, work hours, and wages on health behaviors, using data on business cycles to identify the key exposures of interest. They used the Current Population Survey (CPS) to estimate two-sample instrumental variables (TSIV) models in which work hours and wages were estimated from the CPS and health behaviors were estimated from the BRFSS. The authors found a small but significant negative effect of hours worked on binge drinking of low-wage working age men, suggesting that binge drinking may be somewhat countercyclical.

Findings for cigarette smoking also are mixed. For example, Ruhm (2005), using 19872000 BRFSS data, found procyclical effects (that is, that smoking declines during economic downturns). Xu and Kaestner (2010), using 1984-2005 BRFSS data augmented with data from the CPS and applying their TSIV methodology, found that wages, employment, and hours of work were all positively related to smoking among low-wage men, also providing some evidence that smoking may be procyclical. Charles and DeCicca (2008), using data from the 1997-2001 National Health Interview Surveys, found that the effects of the MSA-level unemployment rate on men's smoking depend on the man's likelihood of being unemployed. For the 10 percent of men most vulnerable to unemployment, higher unemployment rates were associated with higher rates of smoking (that is, smoking appears to countercyclical). For the 10 percent of men least vulnerable to unemployment, higher unemployment rates were associated with lower rates of 
smoking (that is, smoking appears to be procyclical). For the majority of men, unemployment rates were not associated with smoking.

As far as we know, only two population-based studies have examined the effects of the macroeconomy on dietary behaviors. The first is the seminal study by Ruhm (2000), part of which used BRFSS data from 1987-1995 to investigate the effect of state unemployment rates on daily fruit and vegetable consumption. He found a countercyclical but insignificant effect of state unemployment rates on daily consumption of fruits and vegetables. The other study, by Dave and Kelly (2012), investigated the effect of business cycles on the consumption of various types of "healthy" and "unhealthy" foods. Using BRFSS data from 1990-2007, they found countercyclical (but mostly insignificant) effects for unhealthy foods and significant procyclical effects for healthy foods. That is, a higher risk of unemployment was positively related to consumption of snacks and fast food but negatively associated with consumption of fruits and vegetables. The latter study focuses solely on food, examines a broad array of different types of food, and controls for time-related trends by including indicators for month as well as linear, quadratic, and cubic time trends.

Ásgeirsdóttir and Zoega (2011) used the same data as in the current paper to examine sleep behavior. While that paper is mostly theoretical and the empirical focus was not on effects of the economic crisis, the authors do report crude results that indicate increased sleep duration in Iceland in 2009 as compared to 2007. Although analyses tailored to our crisis-specific research questions are needed to fully address the economic impact of the collapse on sleep, the findings of Ásgeirsdóttir and Zoega are in accordance with economic theory in that the opportunity cost of sleep —a time-intensive activity—would decrease as labor market opportunities and returns diminish. In another recent study, Colman and Dave (2011) examined 
physical activity using the American Time Use Survey from 2001-2010 and found that unemployment increases recreational physical activity but reduces overall physical activity as a result of declines in work-related physical activity. They also found evidence that strong economic conditions (high rates of employment) reduce sleep, particularly among women.

Dave and Kelly (2012) attempted to elucidate specific pathways through which recessions affect health behaviors. In contrast, the bulk of the literature has focused on reduced form effects of business cycles (e.g., most of the articles discussed above) or has exploited macroeconomic fluctuations to address related questions (e.g., Xu and Kaestner, 2010). A key objective of the Dave and Kelly study was to explore the extent to which individual variations in work status, real family income, food prices, and health insurance coverage affect "healthy food" consumption, holding constant the state unemployment rate (plus an interaction term for the state unemployment rate multiplied by a propensity score for the individual's probability of unemployment). They found that reduced family income and poor mental health appear to be important channels underlying the procyclical nature of "healthy food" consumption. That is, these pathways explained about half of the negative effect of unemployment on "healthy eating," with the other half remaining unexplained.

\section{Economic crisis in Iceland}

The Icelandic banking sector had expanded dramatically in the years preceding its collapse. At the end of June 2008 the combined assets of Iceland's three largest banks (which, as mentioned earlier, collapsed and became nationalized in October 2008) were 14 times larger than the Gross Domestic Product (GDP) of Iceland, making the Icelandic banking system one of the largest in the world in relation to GDP (International Monetary Fund 2008). According to Nanto (2009), the failure of the banks may have been set in motion by the collapse of Lehman Brothers 
but "at the heart of Iceland's banking crisis is a flawed banking model that is based on an internationally active banking sector that is large relative to the size of the home country's GDP and to the fiscal capacity of the central bank (p. 68)."

The unemployment rate in Iceland increased from 2.3\% in the 1st quarter of 2008 to $7.4 \%$ in the 4 th quarter of 2010 . It peaked in the 2 nd quarter of 2009 , at $9.1 \%$, with the highest rate among young people 16-24 years old, at 21.9\% (Statistics Iceland, 2011). Iceland is one of the world's smallest currency areas, making the krona very vulnerable. The real exchange rate fell by $36 \%$ between 2007 and 2009 despite considerable efforts to maintain the value of the krona, the most important action being the imposition of capital controls in late 2008 to hinder the sales of the local currency (Benediktsdottir, Danielsson and Zoega, 2011). The depreciation in the exchange rate had a significant effect on prices, especially for imported goods. Overall, the Consumer Price Index (CPI) in Iceland increased by 27.3\% between November 2007 and November 2009. Thus everyone, regardless of the effect of the crisis on their individual labor market position, experienced the effects of the crisis through price changes. The prices of domestically-produced goods such as fish oil went up by much less than the CPI overall (18.5\%), while those for goods that are primarily imported, such as alcohol, tobacco products, and fruits, went up by considerably more than the CPI overall $\left(48.7 \%, 40.4 \%\right.$, and $91.8 \%$, respectively). ${ }^{3}$

During the crisis, a large share of the populace lost their savings and became burdened with serious debt. When financing their homes, many families had taken loans in foreign currencies to procure lower interest rates and found themselves trapped in negative equity when the Icelandic krona plummeted. Even those who had taken price-indexed Icelandic loans suffered, as the fall of the local currency resulted in considerable inflation.

The economic crisis in Iceland, with its sudden onset and intensity, likely produced shock

\footnotetext{
${ }^{3}$ Price changes are calculated from November of 2007 to November of 2009. See notes to Table 5 for data sources.
} 
effects that are distinct from regular business cycle effects. More generally, ambient economic conditions can have many different causes, take on many different forms, and have effects that depend on the specific social and institutional contexts. As such, to understand the effects of economic conditions on health and behaviors it is important to compare results across situations, settings, and outcomes. Each additional study adds new information to the picture being painted by the emerging literature. We are aware of only one published study on health effects of the Icelandic economic crisis. Guðjónsdóttir et al. (2011) found an increase in the total number of visits to the cardiac emergency department in general and due to ischaemic heart disease in particular in the days following the address by the Prime Minister. However, this effect was not sustained over time and the authors concluded that it represented a short-term stress reaction.

\section{Contributions of this study}

The unique features of the Icelandic economic crisis in terms of a distinct beginning, magnitude, and velocity, along with the opportunity of obtaining unusually comprehensive, individual-level, nationally representative data on the same Icelanders before and after the country's economic downturn, provides a unique opportunity to investigate the effects of a macroeconomic shock on a wide array of health behaviors. The Icelandic economic crisis is a very strong "treatment" in that the nation's economy rapidly went from boom to bust as a result of an unprecedented shock that was unanticipated by most people but affected everyone in some way. As such, the treatment is more distinct than state-to-state differences and/or over-time fluctuations in economic conditions. In addition, we are studying a very short time interval during which the crisis clearly dominated, precluding the need to account for confounding trends - something that has been a persistent methodological challenge in this literature. Furthermore, because about two thirds of Icelanders live in or near Reykjavik with the rest of the 
population dispersed across the country in small cities and towns, there is essentially one market involved; the findings, therefore, cannot be confounded by regional migration. Finally, because we observe changes in work hours, income, wealth, and mental health with sufficient variation in each, we can directly examine all of those potentially important pathways. Dave and Kelly (2012) were able to explore only some of these factors vis-à-vis food consumption, Colman and Dave (2011) were able to examine only full-time employment vis-à-vis exercise, and Xu and Kaestner (2010) did not have access to substance abuse measures and potential mediating variables for the same individuals. For all of these reasons, the economic crisis in Iceland presents us with a "clean and well-stocked laboratory" in which to study the effects of a macroeconomic downturn on health behaviors and four potential underlying pathways. Furthermore, being able to adjust for those pathways and observe differential price changes across goods provides a unique opportunity to learn about the potential role of prices when investigating the effects of the macroeconomy on the various health behaviors.

\section{Analytic Framework}

We base our analyses on the Grossman-derived demand for health behaviors as described in Xu and Kaestner (2010). In this framework, the demand for a health-related input is a function of the price of that input $\left(\mathrm{P}_{i}\right)$, the prices of a vector of other health-related inputs $\left(\mathrm{P}_{j}\right)$, the prices of a vector of non-health related goods $\left(\mathrm{P}_{x}\right)$, the time inputs for these goods $\left(\mathrm{t}_{\mathrm{i}}, \mathrm{t}_{\mathrm{j}}, \mathrm{t}_{\mathrm{x}}\right)$, and other arguments as follows: $\mathrm{T}_{\mathrm{w}}$ represents work time, or the time not available to consume; $\mathrm{Y}$ represents real income; $\mathrm{Z}$ represents personal characteristics including tastes and preferences; and $\mathrm{e}$ is the person's health endowment.

(1) $D_{i}=D_{i}\left(P_{i}, P_{j}, P_{x}, t_{i}, t_{j}, t_{x}, T_{w}, Y, Z, e\right)$

As discussed above, the economic crisis in Iceland affected the real and relative prices of 
most goods, employment, and real income. Holding constant real income, an increase in the price of any health-related input would be expected to reduce the demand for that input. The relative price increases in Iceland were strongly affected by the devaluation of the krona between 2007 and 2009, such that heavily imported items, such as fruits, had price increases of almost twofold, while local products, such as fresh haddock and lamb, increased by only $18 \%$ and not at all, respectively. All else equal, the large increases in some prices would reduce demand for those goods, whether those goods are health-promoting (such as fruit) or health-compromising (such as cigarettes). Changes in relative prices may affect substitutions of some goods for others as well. For example, an increase in the price of fresh (and imported) fruits may have reduced the demand for those goods relative to other health-promoting items such as locally-produced dairy products, such as skyr.

The effects of the crisis on employment could have affected both time and income constraints. A decrease in work time may have increased the demand for goods-intensive health inputs, such as home-cooked meals, relative to that for fast food. Recession-induced decreases in income, through employment or wealth, would be expected to decrease the demand for all but inferior goods, all else equal. Thus, reductions in income would reduce the consumption of both health-compromising inputs, such as sugared soft drinks or indoor tanning, and health-promoting inputs, such as fruits and vegetables. For all of the price and income effects, the magnitudes would be a function of the own price, cross-price, and income elasticities of demand.

The crisis may also have affected health behaviors through changes in health (e). As discussed earlier, there are many pathways other than behaviors through which recessions could affect health, which may, in turn, affect the demand for health-related inputs. For example, the stresses of long hours of work (during the boom) or financial insecurity (during the bust) could 
have adversely affected mental health, leading to increased consumption of health-compromising inputs such as alcohol or cigarettes. ${ }^{4}$ Or, the society-wide shock of the crisis could have affected social cohesion, which could have affected mental or physical health and, in turn, affected health behaviors. There is some empirical evidence linking social cohesion and health behaviors. For example, Patterson et al. (2004) found smoking to be less prevalent in more socially cohesive neighborhoods.

\section{Data}

The data used for this study come from a health and lifestyle survey "Heilsa og líðan" carried out by the Public Health Institute of Iceland in both 2007 and 2009. Questionnaires were mailed on November $1^{\text {st }}$ in each year and almost all were sent back in November or December of that same year. The survey contained questions about health, illnesses, use of drugs, smoking and drinking, diet, health care, height and weight, accidents, exercise, sleep, and quality of life and other lifestyle related issues, as well as demographics and work related factors such as work hours and income. A stratified random sample of 9,807 Icelanders, ranging in age from 18 to 79 years of age, was drawn. The net response rate in 2007 was $60.8 \%$. Participants from 2007 who agreed to be contacted again also received the 2009 questionnaire; $69.3 \%$ of the 2007 respondents participated in 2009. Due to the stratification in the sampling process, the sample is somewhat older than the adult population of Iceland overall and more likely to live outside the capital region. There were six age groups by two residential groups, forming a total of 12 strata and all results presented here use sample weights to make the sample nationally representative (Jonsson, Gudlaugsson, Gylfason and Guðmundsdóttir, 2011).

Individuals who did not complete the survey in both 2007 and 2009 were excluded from

\footnotetext{
${ }^{4}$ For example, Barnes and Smith (2009) found that, holding income constant, greater financial insecurity is related to a greater probability of continuing to smoke, and Deb at al. (2011) found that job loss is associated with more problem drinking, especially for individuals who are prone to be heavy drinkers.
} 
the analyses. Respondents who completed the 2009 survey were significantly older, less likely to live in an urban area, more likely to be married and less likely to be cohabiting, less likely to be living with a child and less likely to be living with another adult than those who did not complete the 2009 survey (results not shown). However, the sampling weights adjust for attrition and nonresponse based on some of these characteristics to produce nationally representative data. In our analyses, all time-varying variables are based on survey questions that were asked in both 2007 and 2009, except those about changes in assets which were asked about directly in 2009.

We focus on 11 different health behaviors as outcomes. The survey included questions about substance use, which we used to create measures of smoking and heavy drinking. Individuals were coded as being a smoker if they answered the question, "Do you smoke?" with a yes. Respondents were asked how often during the past 12 months, if ever, they had consumed at least 5 alcoholic drinks in one day; that information was used to create a variable for having consumed at least 5 drinks in one day at least once a month during the past 12 months.

The data also include information on dietary behaviors. Respondents were asked about their consumption of a variety of foods, with the question: "How often do you eat the following categories of food?" We focus on daily (versus less than daily) consumption of fruit or berries and of cooked or raw vegetables as health-promoting behaviors, and daily (versus less than daily) consumption of sugar-containing soft drinks and sweets as health-compromising behaviors. Respondents were also asked about their consumption of fast/prepared foods. We consider weekly (versus less than weekly) consumption of fast food (either at a fast food restaurant or by taking home prepared foods) as a health-compromising behavior. Finally, respondents were asked about consumption of fish liver oil or fish oil capsules and vitamins, minerals, other food supplements or health food products, both of which we consider health- 
promoting behaviors (coded as daily, versus less than daily).

The last two behaviors we consider are engaging in indoor tanning at least once in the past year (a health-compromising behavior) and generally receiving 7-9 hours of sleep per night (a health-promoting behavior). Specifically, respondents were asked how often within the last 12 months they sunbathed with indoor tanning lamps or tanning beds while "scantily dressed in order to receive as much sun or radiation as possible" and "(f)or how many hours a night do you generally sleep?" We coded the former as ever (versus never), and based on the U.S. Centers for Disease Control and Prevention (2012) recommendation of 7-9 hours of sleep per night as optimal from a health perspective, we coded individuals as engaging in a health-promoting level of sleep if they reported generally sleeping between 7 and 9 hours (versus outside of that range).

In certain models, we include measures of the respondent's sex, age, and education. Education is categorized as the U.S. equivalents of high school education or less, some college education (but not a four year degree), and at least four years of college education. The question on educational attainment was improved between waves and asked differently in 2009 . Thus, we chose to treat education as time-invariant based first and foremost on the 2009 answers. Given the wide age range of individuals we are examining over a time period of only two years, treating educational attainment as time-invariant seems reasonable, particularly for sub-analyses we conduct for working-age adults (age 25 through 64 years). In many analyses, we include timevarying sociodemographic characteristics: marital/cohabitation status, household composition (including other adults and children), rural residence (an area of fewer than 1,000 inhabitants), and homeownership. In terms of homeownership, the question was: "Do you live in a home you own, in rental housing or in another form of housing?" The respondent was coded as a homeowner if he/she indicated "in a home I own." Finally, in certain models, we explore specific 
pathways through which the crisis may have impacted health behaviors. Specifically, we explore the roles of work hours, real income, wealth, and mental health.

The measures of labor market activity are based on two questions. In the first, respondents were asked to describe their work arrangements. We coded individuals as not working if they answered, "I do not work." In the second, respondents were asked how many hours they generally spend each week doing paid work. They were given 13 response options, including 0 , less than 1 (coded as 1 ), ten categories ranging from 1-3 hours to 50-59 hours, and a top category of 60 hours or more. We used the mid-points of each of the 1-3 through 50-59 ranges and coded responses of 60 hours or more as 60 .

We measure income using the following question: "In what range do you estimate the total income of all household members (e.g. spouse, children and parents) in your household (including yourself) to have been generally...within the past month or within the past 12 months." The respondents were told that this amount should include "all pre-tax income, such as salaries, overtime, differentials, bonuses, interest and dividends, grants/benefits, and pensions." Icelandic benefits come in multiple forms including child benefits, housing benefits, and interest relief. The benefits generally depend on the individual's labor-market income. In the survey, the response choices for income were in ten categories measured in millions of krona, ranging from "less than .9 million krona" and going up to a top category of "more than 18 million krona." Mid-points of the indicated ranges were used, with a top-code for the highest category. Individuals living alone were not asked this question. For those individuals, we used the responses to a question on individual income and coded those responses similarly. As discussed earlier, the price level in Iceland rose by about 27\% between 2007 and 2009, largely as a result of the crisis. To investigate changes in real income between 2007 and 2009, we standardized to 
2009 krona. That is, 2009 real income was equal to 2009 nominal income but 2007 real income was 1.27 times 2007 nominal income.

To measure loss of wealth, we used questions asked in 2009 about the amounts lost in stocks, private pensions, money markets accounts and other savings as a result of the crisis. For each type of asset, measured in millions of krona, respondents were given eight different response choices ranging from "didn't lose any" to "lost more than 30 million krona." We coded at the mid-points of the different ranges, except for the bottom and top ranges which we coded as zero and 30 million, respectively.

We created a measure of "anxiety or poor mental health" based on responses to the following two questions: (1) "Has having any of the following conditions interfered with your daily life in the past 12 months?" One of the response choices was anxiety. (2) "What is your general assessment of your mental health? Do you feel that it is very good, good, fair or poor?" If the respondent reported that anxiety interfered with his/her daily life in the past 12 months or that he/she considered his/her mental health to be poor, we coded him/her as having anxiety or poor mental health. We found that all results were insensitive to all alternative measures of mental health that could be created from the data.

\section{Descriptive Analysis}

All descriptive statistics and regression estimates are weighted to be nationally representative of the Icelandic population. The top panel of Table 1 presents the mean values and sample sizes for the health-compromising behaviors we are studying, for both 2007 and 2009. The second panel presents the corresponding information for the health-promoting behaviors we are studying. The third panel shows means for the time-varying covariates we include in certain models. These are factors, such as the individual's household composition, that could have 
changed as a result of the crisis. The last panel of Table 1 presents means for potential pathways by which the crisis would be expected to affect health behaviors — work hours, real household income, loss in wealth, and anxiety or poor mental health. The first set of columns presents means for the full sample (ages 18-79 years), for 2007 and 2009, respectively, and the second set shows corresponding means for the sub-sample of individuals of working age (ages 25-64). Asterisks represent significant differences between 2007 and 2009 for a given characteristic. The means for the full- and working-age samples are very similar except in terms of the potential mediators. As expected, the working age population was more likely to be in the labor market, worked more hours, and had higher household income than the full sample. That sample reported losing slightly more assets as a result of the crisis also had a higher rate of anxiety or poor mental health.

All of the health-compromising behaviors decreased between 2007 and 2009. Most health-promoting behaviors were also significantly lower in 2009 than in 2007, with the two exceptions being daily consumption of fish oil and getting the recommended amount of sleep, both of which increased significantly between 2007 and 2009. The vast majority (over 95\%) of respondents who reported amounts of sleep outside the recommended range received too little sleep (result not in table). If all observed changes in health behaviors were due to the economic crisis, the 2009 levels minus the 2007 levels of the various behaviors would represent the average effects of the crisis on those behaviors. The observed differences are consistent with studies finding procyclical effects of health-compromising behaviors such as smoking and alcohol consumption (e.g., Ruhm, 2005; Ruhm and Black, 2002), as well as the recent work by Dave and Kelly (2012), which found procyclical effects on consumption of fruits and vegetables, and Colman and Dave (2011), which found countercyclical effects on sleep. 
The only time-varying covariates, of those we considered, that changed significantly between 2007 and 2009 were marital and cohabitation status; marriage increased and cohabitation decreased. There were no significant or substantive differences in rates of coresidence with children, co-residence with an adult other than one's partner, rural residence, or homeownership. The complete lack of change in homeownership rates in Iceland contrasts with the situation in the U.S., where homeownership rates dropped from 68.4 to $67.2 \%$ (representing a decline of $1.8 \%$ ) between the first quarter of 2007 and the last quarter of 2009, and may be due to government interventions in Iceland aimed at helping people stay in their homes. ${ }^{5}$

Considering variables that represent potential pathways, we find that employment and hours worked fell on average after the crisis. In the full sample, the proportion of adults working fell from .82 to .76 (a drop of 7\%; not shown in table), while average work hours dropped from 30.19 to $27.52(8.8 \%)$. Although nominal household income increased somewhat (about 2.8\%, not shown in table), real household income decreased substantially (19.1\%) as a result of the sharp price increases, discussed earlier, that characterized the Icelandic crisis. On average, respondents reported losing 2.037 million krona in assets as a result of the crisis. The proportion of individuals reporting anxiety or poor mental health increased from $25.5 \%$ in 2007 to $28.7 \%$ in 2009. All of these differences are large and statistically significant. ${ }^{6}$

\section{Methodology}

We exploit the shock of the 2008 economic crisis in Iceland to estimate the effects of a macroeconomic downturn on health behaviors. Our primary strategy is to pool the 2007 and 2009 data and estimate individual fixed effects models, which implicitly control for unobserved time-invariant individual-level characteristics and, more importantly for our study, account for

\footnotetext{
${ }^{5}$ Source: http://www.census.gov/hhes/www/housing/hvs/qtr411/q411ind.html [accessed 3/15/12].

${ }^{6}$ We cannot assess significance for the change in wealth, since we do not know the levels at each of the two time points.
} 
cross-period correlation in standard errors. In these models, we estimate each of the 11 health behaviors, with the key variable of interest being an indicator for 2009 (versus 2007) to capture the effects of the 2008 crisis. We estimate those models without any covariates, with the set of time-varying covariates described earlier, and with both time-varying covariates and potential mediators (work hours, real household income, wealth, and mental health) to assess the extent to which those factors appear to explain the effects of the crisis. To assess the potential importance of sample selection as a result of missing data items, we estimate the models with no covariates two different ways - using all possible cases and using our analysis sample, which consists of cases that have non-missing data on all right-hand-side variables (generally about $80 \%$ of the "all possible cases" sample)_ and compare results. We conduct analyses for the full analysis sample, as well as for sub-samples of working age adults and by sex. Finally, we consider the potential role of prices in explaining the effects of the crisis on health behaviors and compute participation elasticities for the various behaviors.

We assess robustness of the full-sample estimates to two alternative estimation strategies, both based on pooled 2007 and 2009 observations without controlling for person-specific effects: (1) probit models, and (2) seemingly unrelated regression models that simultaneously estimate all 11 behaviors. In both cases, we control for the respondent's age, sex, and education and estimate alternative specifications that also include the time-varying covariates and both timevarying covariates and mediators.

Most studies on the effects of financial crises have used such before-and-after designs, but with repeat cross-sectional, rather than longitudinal, data. As such, controlling for potential compositional changes in the population represents a key methodological challenge. Our study is unique in that it uses longitudinal data, allowing us to control for person-specific effects as well 
as relevant time-varying factors. Thus, compositional selection does not complicate our study. However, our study is potentially subject to three other methodological challenges or sources of confounding: pre-existing trends in health behaviors, concurrent trends unrelated to the crisis, and aging of the sample. Below we discuss each of these in turn.

Pre-existing trends

Given our before-and-after research design, it is necessary to demonstrate that the estimated effects of the crisis are capturing shocks rather than continuations of ongoing longterm trends in health behaviors. Figures $1-4$ show pre-crisis trends in four of the health-related behaviors of interest. Data on alcohol sales are available from 1980 through 2007. Survey data on smoking are available from 1994 through 2010 and on fruit and vegetable consumption from 1960 through 2010. As shown in Figure 1, alcohol sales had been rising in Iceland since the early 1990s. From Figure 2 we can see that smoking had been declining until about 2004, then started to plateau, and then appeared to resume its decline in $2008 .^{7}$ Figures 3 and 4 show clear longterm upward trends in fruit and vegetable consumption through 2007 and then sudden and sustained drops after the crisis. We will consider our estimated effects in light of these baseline trends.

\section{Concurrent trends}

It is possible that the effects of the crisis reflect other unrelated trends. Given the unique features of the Icelandic economic crisis (the distinct beginning, magnitude, and velocity; the single market; and the shock to most people that affected everybody) and our relatively short observation window of 2 years, it is likely that other trends, if any, paled in comparison. For

\footnotetext{
${ }^{7}$ Between 2001 and 2004, before the boom or the crisis, daily smoking decreased from $22.9 \%$ of the population to $19.8 \%$--over 3 percentage points. Between 2004 and 2007, during the boom, daily smoking decreased from 19.8\% to $19.0 \%$--a decline of less than one percentage point. In the subsequent years, from 2007 to 2010, daily smoking fell to $14.2 \%$ of the population.
} 
example, Iceland enacted a smoking ban in restaurants and bars in Iceland on June 1 of $2007-$ five months prior to the first survey. As such, it is theoretically possible that part of the crisis effect for this particular behavior, should we find one, reflects the restaurant smoking ban. However, Wakefield et al. (2008) and Tauras (2006) found that although smoking bans may impact the quantity of consumption, they do not appear to impact smoking prevalence. Thus, the smoking ban in restaurants and bars in Iceland is not expected to have affected smoking prevalence in the country. In addition, it could not explain the crisis effects for most other behaviors, which were not subject to legislative changes.

Aging of sample

Given our reliance on longitudinal rather than repeat cross-sectional data, observed crisis effects could theoretically be picking up an aging effect. That is, every single individual in the sample aged two years between 2007 and 2009 and health behaviors can change with age, particularly at very young and old adult ages. We addressed this issue two ways: (1) estimating pooled probit models (which do not control for person-specific effects or adjust for cross-period correlation in standard errors) and controlling for age, and (2) conducting analyses on the subsample of adults who were of working age (25-64 in 2007), a group for whom two years of age should have relatively small effects on behaviors. The analyses of working age individuals are also of substantive interest, as that group is expected to have been particularly affected by the crisis through changes in employment. Finally, the analyses of working age individuals have the added advantage that educational attainment probably did not change between 2007 and 2009 for the vast majority of this group. As such, using 2009 education (instead of time-varying education in the relevant specifications) becomes much less consequential. This issue vis-à-vis education does not pertain to our preferred estimates, the fixed effects models. 


\section{Multivariate analysis}

Tables $2 \mathrm{a} \& \mathrm{~b}$ present our primary results - fixed effects estimates of the effects of the crisis on the various health-compromising (Table $2 \mathrm{a}$ ) and health-promoting (Table $2 \mathrm{~b}$ ) behaviors. We present fixed effects regression coefficients and standard errors. In the first row, we present estimated effects of the crisis, characterized using an indicator for 2009 , when no observations are dropped due to missing right-hand-side variables. The second row presents corresponding estimates for our analysis sample which exclude observations with missing data on right-handside variables. We find that for all 11 health behaviors, the estimated effects of the crisis from the restricted sample (second row) fall within one standard error of those from the full sample (top row) and that significance levels are quite similar in the two specifications. Thus, our estimates are reasonably robust to the exclusion of observations with missing data on right-handside variables. From the second row in Table $2 \mathrm{a}$, we can see that the estimated effects of the crisis - the 2009 indicators — are negative and significant for all health-compromising behaviors - smoking, heavy drinking, sugared soft drinks, sweets, fast food, and indoor tanning. The estimated effects are quite similar to the corresponding mean differences in Table 1, underscoring that the crisis was an exogenous shock.

Because alcohol sales were increasing steadily prior to the crisis (Figure 1) and may have continued to climb into 2009 in the absence of the crisis, the estimated effects of the crisis on that behavior may be suppressed (that is, we may be underestimating the effects of the crisis). In contrast, because smoking had been trending down before the crisis began (Figure 2), we may be overestimating the negative effects of the crisis on smoking. That said, the average reduction in smoking from 2005 to 2007 was about $.26 \%$ per year. If the same trend had continued, we would 
have seen a reduction in smoking of .005 percentage points for the two years, rather than the observed .03 percentage point reduction.

From the second row in Table $2 \mathrm{~b}$, we can see that the crisis also significantly reduced certain health-promoting behaviors and increased others. Specifically, the crisis reduced consumption of fruits and vegetables but increased consumption of fish oil and recommended sleep. There were no significant effects of the crisis on consumption of vitamins or supplements. As in Table $2 \mathrm{a}$, we find that the estimated effects are quite similar to the corresponding mean differences in Table 1. As the consumption of both fruits and vegetables had been increasing before the crisis (Figures 3 and 4) and may have continued to rise in the absence of the crisis, it is possible that we are underestimating the effects of the crisis on fruit and vegetable consumption.

The estimated effects for heavy drinking are consistent with those of Ruhm (2002), who found drinking to be pro-cyclical, and for smoking are consistent with those of Ruhm (2005) and $\mathrm{Xu}$ and Kaestner (2010), who found smoking to be pro-cyclical. Our findings for healthpromoting dietary behaviors are consistent with those of Dave and Kelly (2012) in that we found pro-cyclical effects for health-compromising behaviors, but are at odds with the findings from that study of weak counter-cyclical effects on health-promoting behaviors.

The estimates in the third row of Tables $2 \mathrm{a} \& \mathrm{~b}$ are from fixed effects models that also include our basic set of time-varying covariates. ${ }^{8}$ As such, these estimates represent the effects of the crisis holding constant changes in marital and cohabitation status, household composition, rural residence, and homeownership. Including the time-varying covariates does not appreciably affect our estimates of the effects of the crisis on health behaviors.

\footnotetext{
${ }^{8}$ It is important to point out that the set of factors we refer to as "time-varying covariates" potentially mediate the effects of the crisis. However, these are not the mediators of particular interest in this study
} 
The estimates in the fourth rows are from fixed effects models that include the timevarying covariates plus the four potential mediators of interest—hours of work, real household income, loss of wealth, and anxiety or poor mental health. ${ }^{9}$ For health-compromising behaviors (Table 2a), we find that the mediators reduce the estimated effects of the crisis on healthcompromising behaviors by $9 \%$ (smoking) to $42 \%$ (heavy drinking). For health-promoting behaviors (Table 2b), the mediators reduced the impact of the crisis in two cases, for fish oil and vitamins/supplements (by 36\% for each). These contributions of the mediating factors are in the range found by Dave and Kelly (2012). Given that such a substantial portion of the effects of the crisis remains unexplained by the most obvious individual pathways and that the shock was so strong and universal, it is likely that the shock operated, at least to some extent, through the broader environment (i.e., though changes that affected everybody, such as price increases). ${ }^{10}$ Analyses (not shown) in which the mediators were included individually, rather than in sets of four, reveal that real income is the most important of the four mediators. Each of the other three mediators - hours of work, wealth, and mental health — contributed little to explaining the effects of the crisis on health behaviors.

Appendix Tables $1 \mathrm{a} \& \mathrm{~b}$ present estimates corresponding to those from the second row of Tables $2 \mathrm{a} \& \mathrm{~b}$, but from pooled probit models which include controls for 2007 age, 2007 age squared, sex, and 2009 education. Each cell includes the relevant probit coefficient, standard

\footnotetext{
${ }^{9}$ In order for a factor to mediate the effect of the crisis on other outcomes, that factor must itself be affected by the crisis. We thus considered the effects of the crisis on the potential mediating factors of interest - work hours, real income, wealth, and mental health. These results are presented in Appendix Table 2. Considering each of the potential mediators as an outcome, we estimated unadjusted fixed effects models and fixed effects models that included the set of time-varying covariates. We find that Icelanders worked 2.7 fewer hours, experienced a 1.67 million krona drop in real family income (expressed in 2009 krona), experienced a 2.04 million krona drop in wealth and were about 3 percentage points about $12 \%$ ) more likely to report anxiety or poor mental health as a result of the crisis. Both sets of fixed effects estimates were very similar to those from corresponding pooled OLS (for hours worked, income, and loss in wealth) or probit (for anxiety or poor mental health) estimates (not shown), as well as to the corresponding mean differences in Table 1 . That is, neither time-invariant factors nor observed time-varying factors have any bearing on our estimated effects of the crisis on these potential mediating factors. Overall, it is clear that the crisis affected all four mediators in the expected directions.

${ }^{10}$ Estimates are insensitive to alternative definitions of the outcomes and mediating variables.
} 
error (in parentheses) and marginal effect [in brackets]. It is reassuring that the marginal effects from the probit models are quite similar to those from the fixed effects models, providing a robustness check to our functional form. In addition, these models indicate that while age is a significant determinant of the various behaviors, the estimated effects of age are small compared to those of the crisis, suggesting that the estimated effects of the crisis in our fixed effects models in Tables $2 \mathrm{a} \& \mathrm{~b}$ are not substantially confounded by the aging of the sample by two years. Additional pooled probit specifications that included the time-varying covariates and the timevarying covariates plus mediators also produced estimates very similar to the corresponding fixed effects estimates in Tables $2 \mathrm{a} \& \mathrm{~b}$ (results not shown).

As indicated in Equation 1, the demand for the different health behaviors may not be independent of one another. To address this possibility, we simultaneously estimated the demand for the 6 health-compromising behaviors and 5 health-promoting behaviors using seemingly unrelated regression (SUR) models. These results, based on the pooled 2007 and 2009 data but not accounting for person-specific effects, are presented in Tables $3 a \& b$. The first three rows present estimates from SUR models that included only age, sex, and education (row 1), age, sex, and education plus time-varying covariates (row 2), and age, sex, and education plus timevarying covariates and mediators (row 3). For comparison, rows 4 through 6 present results from linear probability models that correspond to those in rows 1 through 3 except the behaviors are considered independent (i.e., estimated as separate equations). In all cases, the linear probability estimates are similar to those from both the corresponding fixed effects models (from Tables 2a $\&$ b) and pooled probit models (Appendix Tables 1a \& b). In addition, coefficients from the linear probability and SUR models are almost identical to one another. Thus, estimates in Tables 2a \& b, Tables 3a \& b, and Appendix Tables $1 \mathrm{a} \& \mathrm{~b}$ indicate that our estimates are not sensitive 
to functional form.

In Tables $4 \mathrm{a} \& \mathrm{~b}$, we restrict the fixed effects analyses to individuals of working agethose aged 25-64 years in 2007, the group that should be most affected by changes in employment and for whom two years of aging should have minimal effects on health behaviors, on average. The age restriction at the top end is based on the statutory retirement age in Iceland of $67 .{ }^{11}$ As expected, effects of the crisis on health-compromising behaviors were stronger for the working-age population than for the adult population overall. For example, fast food consumption decreased by about 6.1 percentage points (Table $4 a$ ) compared to about 3.9 percentage points for the overall population (Table 2a). In general, the impacts of the crisis on health-promoting behaviors were somewhat weaker for the working-age population than for the full sample. The only exception was for recommended sleep, for which the effect was greater for the working age population.

Based on findings of significant differences in effects of economic conditions on health behaviors for men and women by Dave and Kelly (2012), we estimated models corresponding to those in Tables $2 \mathrm{a} \& \mathrm{~b}$ but stratified by sex. These estimates are presented in Appendix Tables $3 \mathrm{a}$ $\& \mathrm{~b}$ (for men) and $4 \mathrm{a} \& \mathrm{~b}$ (for women). We find that the crisis had stronger negative (favorable) effects on heavy drinking, soft drink consumption, and fast food consumption for men than for women, while it had stronger negative (favorable) effects on consumption of sweets and indoor tanning for women than for men. The crisis reduced fruit and vegetable consumption more for women than for men. For fish oil consumption, the positive effects of the crisis were much stronger for women than men. In contrast, the beneficial effects of the crisis on sleep were concentrated among men. In analyses that included the potential mediators (not shown), we

\footnotetext{
${ }^{11}$ Source: http://www.aarpinternational.org/map_country/map_country show.htm?doc id=545826
} 
continue to find that changes in work hours, real household income, wealth, and anxiety or poor mental health do not explain the bulk of the observed behavioral changes.

\section{The Role of Prices}

As discussed, above, much of the impact of the economic shock does not seem to be mediated by individuals' changes in hours of work, real income, wealth, or mental health. From this, we infer that there were economy-wide factors at work. An obvious starting point for economy-wide changes that would affect the demand for health-related behaviors is prices, given the importance of price in any demand equation and the large price increases characterizing the Icelandic economic crisis. As indicated earlier, prices increased over 27\% between 2007 and 2009 based on Iceland's overall CPI; this compares to a 3.4\% in the U.S. CPI over the same two year period. ${ }^{12}$ In addition, there was substantial variation in price changes across commodities, with price increases ranging from $18.5 \%$ for fish oil to over $90 \%$ for fruits. Table 5 summarizes the nominal price changes (column 1), real price changes (column 2), and participation changes net of mediators (column 3), all calculated in percentage terms, as well as the "participation elasticity" for each of the health-related behaviors that can be purchased in the market (column 4) and the $10 \%$ confidence interval for the elasticity estimate. The participation changes were calculated by dividing the coefficients in the bottom row of coefficients in Tables $2 \mathrm{a} \& \mathrm{~b}$, which indicate the effects of the crisis on the behavior net of individual time-varying and mediating factors, by the mean value of the behavior in 2007 from Table 1 .

If all of the society-wide changes in consumption were a result of price changes, then we could calculate price elasticities of demand for our health-related participation behaviors. If other society-wide factors were at work, then our participation elasticities will reflect the impacts of both prices and other society-wide changes, such as a potential increase (decrease) in social

\footnotetext{
${ }^{12}$ Source: $\mathrm{ftp} / / / \mathrm{ftp}$. bls.gov/pub/special.requests/cpi/cpiai.txt [accessed 3/21/12].
} 
cohesion. For example, President Grimsson speculated that Iceland became even more socially cohesive in the wake of the crisis (Grimsson, 2011). If social cohesion did, in fact increase, and if increased social cohesion lead to reductions in health-compromising behaviors (a scenario mentioned earlier), then we may be overestimating the price elasticities of demand for healthcompromising behaviors. As such, our participation elasticities represent preliminary estimates of the price elasticities of demand for a variety of health-related behaviors, holding constant the general price level (i.e., prices of all other goods), real income, hours of work, wealth, and mental health. Despite this caveat, our calculations provide a useful starting point for examining elasticities for the range of behaviors, many of which have not been calculated in the context of examining the impact of economic conditions on health behaviors. ${ }^{13}$

We estimate the participation elasticity of heavy drinking to be -0.33 , which is quite similar to a -0.28 elasticity for heavy drinking found in a recent meta-analysis by Wagenaar et al. (2009). Our estimated smoking participation elasticity of -1.1 is similar to an estimate in Gallus et al. (2006) of an elasticity of -1.0 for non-EU countries in Europe. ${ }^{14}$ The fact that our elasticities for alcohol and tobacco are of magnitudes that are plausible and consistent with previous studies suggests that those for the less-studied health behaviors are also realistic. From our calculations, we infer that a substantial part of the effects of the crisis in Iceland on health behaviors, particularly vis-à-vis heavy drinking and smoking (for which a comparison to the literature can be made), is likely price related.

We find an inelastic response to price changes for sugared soft drinks whereas the

\footnotetext{
${ }^{13}$ Dave and Kelly (2012), in their investigation of business cycles on "healthy" eating were unable to assess price effects, due to the weak correlation between food prices and unemployment as well as noise in their price data (from ACCRA), which are based on a small number of observations per city.

${ }^{14}$ Given that smoking prevalence had been experiencing a downward trend and alcohol sales an upward trend in Iceland (Figures 1 and 2), it is possible that the elasticity for smoking is somewhat overestimated and that for heavy drinking is underestimated.
} 
responses for sweets, indoor tanning, and fast food were price elastic (in increasing order of magnitude). Unlike the other outcomes, the measure of fast food is based on a very general and heterogeneous category which includes "prepared foods"; as such, our measure of its price may not reflect a true weighted average reflecting prices and availability. In addition, it likely captures some extreme supply-side changes. ${ }^{15}$ Health-promoting behaviors revealed less price sensitivity, overall, compared to health-compromising behaviors. For fruits, vitamins/supplements, and fish oil, demand was inelastic, whereas for vegetables the elasticity was approximately unitary. ${ }^{16}$

\section{Conclusion}

The 2008 economic crisis in Iceland led to reductions in all health-compromising behaviors examined—smoking; heavy drinking; consumption of sugared soft drinks, sweets, and fast food; and indoor tanning. It also led to reductions in certain health-promoting behaviors but increased others. Specifically, the crisis reduced consumption of fruits and vegetables but increased consumption of fish oil and getting the recommended amount of sleep. Generally, the effects of the crisis on health-compromising behaviors were stronger for the working-age population than for the adult population overall.

Changes in hours of work, real household income, wealth, and mental health explained some of the effects on health-compromising behaviors, ranging from $9 \%$ for smoking to $42 \%$ for heavy drinking. For health-promoting behaviors, these factors reduced the effects of the crisis only for fish oil and vitamins/supplements, by about one third. We inferred that broad-based factors — such as prices, which increased over 27\% in Iceland between 2007 and 2009—played a

\footnotetext{
${ }^{15}$ For example, McDonald's ceased to operate in Iceland at the end of October 2009, citing a doubling of production costs (Valdimarsson, 2009).

${ }^{16}$ If the (unobserved) pre-crisis trends were upward as for fruit and vegetable consumption (Figures 3 and 4), the elasticities for other health-promoting behaviors (vitamins/supplements and fish oil) may be underestimated.
} 
large role in the effects of the crisis on health behaviors. We exploited our ability to isolate behavioral changes that are likely due, at least in large part, to price changes, to compute participation elasticities for the various goods. We found inelastic responses to price changes for alcohol and sugared soft drinks and elastic responses for smoking, sweets, indoor tanning, and fast food. Health-promoting behaviors revealed less price sensitivity overall compared to healthcompromising behaviors.

We investigated the effects of a severe macroeconomic downturn over a short observation period during which few other potentially confounding changes occurred. Previous studies of the effects of macroeconomic conditions on health behaviors have not had this advantage and have rarely been able to examine a broad array of behaviors, control for personspecific effects, consider potential interdependence across behaviors, explore potential individual-level pathways, or consider the potential role of price changes. As such, this studywhich does all of these things - makes an important contribution to the literature on the effects of macroeconomic conditions on health behaviors and health. 


\section{References}

Ásgeirsdóttir, T.L., and G. Zoega. (2011). On the economics of sleeping. Mind \& Society, 10(2), 149-164.

Barnes, M.G., and T.G. Smith. (2009). Tobacco use as response to economic insecurity: evidence from the National Longitudinal Survey of Youth. The B.E. Journal of Economic Analysis \& Policy, 9(1) (Contributions), Article 47, 1-27. Available at http://www.bepress.com/bejeap/vol9/iss1/art47

Benediktsdottir, S., Danielsson, J., and G. Zoega. (2011). Lessons from a collapse of a financial system. Economic Policy, 26(66), 183-235.

Charles, K.K., and P. DeCicca. (2008). Local labor market fluctuations and health: is there a connection and for whom? Journal of Health Economics, 27(6), 15321550.

Colman, G.J., and D.M. Dave. (2011). Exercise, physical activity, and exertion over the business cycle. National Bureau of Economic Research Working Paper No. 17406.

Dave, D.M., and I.R. Kelly. (2012). How does the business cycle affect eating habits? Social Science \& Medicine, 74(2), 254-262.

Davlos, M., Fang, F., and M. French. (2012 Forthcoming). Easing the pain of an economic downturn: macroeconomic conditions and excessive alcohol consumption, Health Economics. DOI: 10.1002/hec.1788

Deb, P., Gallo, W., Ayyagari, P., Fletcher, J.M., and J.L. Sindelar. (2011). Job loss: eat, drink and try to be merry? National Bureau of Economic Research Working Paper No. 15122.

Dee, T.S. (2001). Alcohol abuse and economic conditions: evidence from repeated cross-sections of individual-level data. Health Economics, 10(3), 257-270.

Gallus, S., Schiaffino, A., La Vecchia, C., Townsend, J., \& Fernandez, E. (2006). Price and cigarette consumption in Europe. Tobacco Control, 15(2), 114-119.

Grimsson, Olafur Ragnar. (2011). Interview with President of Iceland aired on Swedish public TV2 network news on Nov. 28, 2011. See: http://politicalvelcraft.org/2011/12/11/icelandpresident-on-crisis-we-allowed-the-banks-to-fail-and-in-the-end-we-were-blessed-withour-own-currency/ [Accessed 6/30/12].

Guðjónsdóttir, G. R., Kristjánsson, M. Ólafsson, Ö, Arnar, D. O., Getz, L., Sigurðsson, J. Á. Guðmundsson, S., and U. Valdimarsdottir. (2011). Immediate surge in female visits to the cardiac emergency department following the economic collapse in Iceland: an observational study. Emergency Medicine Journal. (Online) DOI:10.1136/emermed2011-200518 
International Monetary Fund. (2008). Iceland: Request for Stand-By Arrangement-Staff Report; IMF Country Report No. 08/362.

Jonsson, S.H., Guðlaugsson, J.O., Gylfason, H.F., and Guðmundsdóttir, D.G. (2011). Heilsa og líðan Íslendinga 2007: Framkvæmdaskýrsla. Reykjavík: Lýðheilsustöð. Retrieved March 15, 2011 from http://www.lydheilsustod.is/rannsoknir/heilsa-og-lidan-2007

Nanto, D.K. (2009). The global financial crisis: analysis and policy implications. Congressional Research Services, Report for Congress. Available at: http://www.fas.org/sgp/crs/misc/RL34742.pdf [Accessed 3/23/12].

Pacula, R.L. (2011). Substance use and recessions: what can be learned from economic analyses of alcohol? International Journal of Drug Policy, 22(5), 326-434.

Patterson, J.M, Eberly, L.E., Ding, Y., and Margaret Hargreaves, M. (2004). Associations of smoking prevalence with individual and area level social cohesion. Journal of Epidemiology and Community Health, 58(8), 692-697.

Prime Minister's Office. (2008). Address to the Nation by H.E. Geir H. Haarde, Prime Minister of Iceland, October 6th 2008.

Ruhm, C. J. (2000). Are recessions good for your health? The Quarterly Journal of Economics. $115(2), 617-650$.

Ruhm, C. J., and Black, W. E. (2002). Does drinking really decrease in bad times? Journal of Health Economics. 21(4), 659-678.

Ruhm, C. J. (2003). Good times make you sick. Journal of Health Economics, 22(4), 637-658.

Ruhm, C. J. (2005). Healthy living in hard times. Journal of Health Economics, 24(2), 341-363.

Statistics Iceland. (2010). Disposable income of the household sector 2009. Report No. 192/2010. Retrieved from: http://www.statice.is/?PageID=444\&NewsID=5304.

Statistics Iceland. (2011). Activity rate, unemployment and labour force by quarters. Retrieved from: http://www.statice.is/Statistics/Wages,-income-and-labour-market/Labour-market.

Tauras, J. A. (2006). Smoke-Free Air Laws, Cigarette Prices, and Adult Cigarette Demand. Economic Inquiry, 44(2), 333-342.

The Public Health Institute of Iceland. (2012a). Retrieved from: http://www2.lydheilsustod.is/rannsoknir/matur-mataraedi-holdafar/frambod-og-sala-a$\underline{\text { matvoru/nr/2905 }}$

The Public Health Institute of Iceland. (2012b). Retrieved from: http://www2.lydheilsustod.is/rannsoknir/tobak-og-tobaksvarnir/skyrslur/ 
U.S. Centers for Disease Control and Prevention. (2012). Sleep and sleep disorders. Available at: http://www.cdc.gov/Features/Sleep/ [Accessed 3/20/12].

Vilaplana, C., Labeaga, José M., and S. Jiménez-Martín. (2006). Further evidence about alcohol consumption and the business cycle. Working Paper. 2006-06, FEDEA.

Wagenaar, A. C., Salois, M. J., \& Komro, K. A. (2009). Effects of beverage alcohol price and tax levels on drinking: a meta-analysis of 1003 estimates from 112 studies. Addiction, 104(2), 179-190.

Wakefield, M. A., Durkin, S., Spittal, M. J., Siahpush, M., Scollo, M., Simpson, J. A., ... Hill, D. (2008). Impact of Tobacco Control Policies and Mass Media Campaigns on Monthly Adult Smoking Prevalence. American Journal of Public Health, 98(8), 1443-1450.

$\mathrm{Xu}, \mathrm{X}$., and R. Kaestner. (2010). The business cycle and health behaviors. National Bureau of Economic Research Working Paper No. 15737. 


\begin{tabular}{|c|c|c|c|c|}
\hline & \multicolumn{2}{|c|}{$\begin{array}{l}\text { Full Sample } \\
18-79 \text { years }\end{array}$} & \multicolumn{2}{|c|}{$\begin{array}{l}\text { Working Age } \\
25-64 \text { years }\end{array}$} \\
\hline & 2007 & 2009 & 2007 & 2009 \\
\hline \multicolumn{5}{|l|}{ Health-Compromising Behaviors } \\
\hline Currently smokes cigarettes or other tobacco product & $.209 * * *$ & .176 & $.225^{* * *}$ & .187 \\
\hline $5+$ alcoholic drinks in 1 day at least 1 time/month (past year) & $.221 * * *$ & .195 & $.204^{* * *}$ & .174 \\
\hline Daily sugared soft drink & $.089 * *$ & .074 & $.080 * * *$ & .064 \\
\hline Daily Sweets & $.091 * * *$ & .066 & $.093 * * *$ & .066 \\
\hline Weekly fast food & $.316 * * *$ & .267 & $.315^{* * *}$ & .248 \\
\hline Indoor tanning (past 12 mos.) & $.178^{* * *}$ & .141 & $.170 * * *$ & .127 \\
\hline \multicolumn{5}{|l|}{ Health-Promoting Behaviors } \\
\hline Daily fruit & $.371 * *$ & .349 & .372 & .354 \\
\hline Daily vegetable & $.285^{* * *}$ & .255 & $.292 * * *$ & .263 \\
\hline Daily fish oil & $.380 * * *$ & .406 & $.363 * * *$ & .393 \\
\hline Daily Vitamins/Supplements & .885 & .874 & .883 & .874 \\
\hline Gets recommended sleep (7-9 hours/night) & $.727^{* * *}$ & .765 & $.722 * * *$ & .763 \\
\hline \multicolumn{5}{|l|}{ Time-Varying Covariates } \\
\hline Married & $.547 * * *$ & .573 & $.592 * * *$ & .626 \\
\hline Cohabiting & $.200 * * *$ & .178 & $.215^{* * *}$ & .180 \\
\hline Child in household & .402 & .392 & $.502 * * *$ & .480 \\
\hline Lives with adult other than partner & .274 & .261 & .258 & .258 \\
\hline Lives in rural area & .116 & .111 & .117 & .113 \\
\hline Homeowner & .797 & .790 & .854 & .852 \\
\hline \multicolumn{5}{|l|}{ Potential Mediators } \\
\hline Hours of work $(* .10)$, mean & $3.019 * * *$ & 2.752 & $3.520 * * *$ & 3.260 \\
\hline Real household income (millions of 2009 krona/year), mean & $8.732 * * *$ & 7.068 & $9.387 * * *$ & 7.623 \\
\hline Loss in wealth (millions of krona), mean & $\mathrm{n} / \mathrm{a}$ & 2.037 & $\mathrm{n} / \mathrm{a}$ & 2.197 \\
\hline Anxiety or poor mental health & $.255^{* * *}$ & .287 & $.265^{* * *}$ & .299 \\
\hline
\end{tabular}

Notes: P-values are from t-tests for differences in means between 2007 and 2009. Exchange rate was about 123 krona to the U.S. dollar at the end of November 2009 (Source:

http://online.wsj.com/mdc/public/page/2 3020-worlddollar-20091127.html?mod=mdc pastcalendar). Thus, 1 million krona translates to about $\$ 8,150$ U.S. 
Table 2a: Effects of Economic Crisis in Iceland on Health-Compromising Behaviors-Fixed Effects Models

\begin{tabular}{|c|c|c|c|c|c|c|}
\hline & Smoking & $\begin{array}{l}\text { Heavy } \\
\text { Drinking }\end{array}$ & $\begin{array}{c}\text { Daily Sugared } \\
\text { Soft Drink }\end{array}$ & Daily Sweets & $\begin{array}{l}\text { Weekly Fast } \\
\text { Food }\end{array}$ & $\begin{array}{l}\text { Indoor } \\
\text { Tanning }\end{array}$ \\
\hline Effects of 2009 indicator: & $\begin{array}{c}\text { Coefficient } \\
\text { (SE) }\end{array}$ & $\begin{array}{c}\text { Coefficient } \\
\text { (SE) }\end{array}$ & $\begin{array}{l}\text { Coefficient } \\
\text { (SE) }\end{array}$ & $\begin{array}{l}\text { Coefficient } \\
\text { (SE) }\end{array}$ & $\begin{array}{l}\text { Coefficient } \\
\text { (SE) }\end{array}$ & $\begin{array}{l}\text { Coefficient } \\
\text { (SE) }\end{array}$ \\
\hline Full sample, with no covariates & $\begin{array}{c}-.033^{* * *} \\
(.006) \\
\mathrm{N}=7466\end{array}$ & $\begin{array}{c}-.018 * * \\
(.007) \\
N=7526\end{array}$ & $\begin{array}{c}-.013^{* *} \\
(.005) \\
\mathrm{N}=7566\end{array}$ & $\begin{array}{c}-.020 * * * \\
(.005) \\
\mathrm{N}=7596\end{array}$ & $\begin{array}{c}-.046 * * * \\
(.008) \\
\mathrm{N}=7688\end{array}$ & $\begin{array}{c}-.035^{* * *} \\
(.006) \\
\mathrm{N}=7082\end{array}$ \\
\hline \multicolumn{7}{|l|}{ Dropping cases with missing data: } \\
\hline With no covariates & $\begin{array}{c}-.033 * * * \\
(.006)\end{array}$ & $\begin{array}{c}-.025 * * * \\
(.008)\end{array}$ & $\begin{array}{c}-.015^{* *} \\
(.006)\end{array}$ & $\begin{array}{c}-.025 * * * \\
(.006)\end{array}$ & $\begin{array}{c}-.049 * * * \\
(.009)\end{array}$ & $\begin{array}{c}-.037 * * * \\
(.007)\end{array}$ \\
\hline With time-varying covariates & $\begin{array}{c}-.034 * * * \\
(.006)\end{array}$ & $\begin{array}{c}-.026 * * * \\
(.008)\end{array}$ & $\begin{array}{c}-.015 * * \\
(.006)\end{array}$ & $\begin{array}{c}-.024 * * * \\
(.006)\end{array}$ & $\begin{array}{c}-.048 * * * \\
(.009)\end{array}$ & $\begin{array}{c}-.036 * * * \\
(.007)\end{array}$ \\
\hline $\begin{array}{l}\text { With time-varying covariates plus } \\
\text { mediators }\end{array}$ & $\begin{array}{c}-.031^{* * *} \\
(.007)\end{array}$ & $\begin{array}{l}-.015 \\
(.010)\end{array}$ & $\begin{array}{l}-.012^{*} \\
(.006)\end{array}$ & $\begin{array}{c}-.021 * * * \\
(.007)\end{array}$ & $\begin{array}{c}-.039 * * * \\
(.010)\end{array}$ & $\begin{array}{c}-.031 * * * \\
(.009)\end{array}$ \\
\hline $\mathbf{N}$ & 5842 & 5858 & 5902 & 5888 & 5946 & 5620 \\
\hline
\end{tabular}

Notes: SE = Standard error. Sample weights are applied. "2009 indicator" indicates the effect of the crisis. Time-varying covariates are married, cohabiting, lives with adult other than partner, lives in rural area, and homeowner. Mediators are hours of work, real income, wealth, and anxiety or poor mental health. ${ }^{*} \mathrm{p}<.10 ;{ }^{* *} \mathrm{p}<.05 ;{ }^{* *} \mathrm{p}<.01$. 
Table 2b: Effects of Economic Crisis in Iceland on Health-Promoting Behaviors-Fixed Effects Models

\begin{tabular}{|c|c|c|c|c|c|}
\hline & Daily Fruit & Daily Vegetable & Daily Fish Oil & $\begin{array}{l}\text { Daily Vitamins/ } \\
\text { Supplements }\end{array}$ & $\begin{array}{l}\text { Recommended } \\
\text { Sleep }\end{array}$ \\
\hline Effects of 2009 indicator: & $\begin{array}{l}\text { Coefficient } \\
\text { (SE) }\end{array}$ & $\begin{array}{l}\text { Coefficient } \\
\text { (SE) }\end{array}$ & $\begin{array}{l}\text { Coefficient } \\
\text { (SE) }\end{array}$ & $\begin{array}{l}\text { Coefficient } \\
\text { (SE) }\end{array}$ & $\begin{array}{l}\text { Coefficient } \\
\text { (SE) }\end{array}$ \\
\hline Full sample, with no covariates & $\begin{array}{c}-.024^{* * *} \\
(.009) \\
\mathrm{N}=7738\end{array}$ & $\begin{array}{c}-.022 * * * \\
(.009) \\
\mathrm{N}=7776\end{array}$ & $\begin{array}{c}.031 * * * \\
(.009) \\
\mathrm{N}=7618\end{array}$ & $\begin{array}{c}-.011 \\
(.007) \\
\mathrm{N}=7138\end{array}$ & $\begin{array}{c}.034 * * * \\
(.009) \\
\mathrm{N}=7648\end{array}$ \\
\hline \multicolumn{6}{|l|}{ Dropping cases with missing data: } \\
\hline With no covariates & $\begin{array}{l}-.022 * * \\
(.010)\end{array}$ & $\begin{array}{c}-.030 * * * \\
(.010)\end{array}$ & $\begin{array}{c}.026 * * * \\
(.010)\end{array}$ & $\begin{array}{l}-.010 \\
(.007)\end{array}$ & $\begin{array}{c}.038 * * * \\
(.010)\end{array}$ \\
\hline With time-varying covariates & $\begin{array}{c}.021^{* *} \\
(.010)\end{array}$ & $\begin{array}{c}-.030 * * * \\
(.010)\end{array}$ & $\begin{array}{l}.028 * * * \\
(.010)\end{array}$ & $\begin{array}{l}-.011 \\
(.007)\end{array}$ & $\begin{array}{c}.039 * * * \\
(.010)\end{array}$ \\
\hline $\begin{array}{l}\text { With time-varying covariates plus } \\
\text { mediators }\end{array}$ & $\begin{array}{l}-.028 * * \\
(.011)\end{array}$ & $\begin{array}{c}-.032 * * * \\
(.011)\end{array}$ & $\begin{array}{c}.018 \\
(.011) \\
\end{array}$ & $\begin{array}{l}-.007 \\
(.008)\end{array}$ & $\begin{array}{l}.045^{* * *} \\
(.011)\end{array}$ \\
\hline $\mathbf{N}$ & 5932 & 5868 & 5802 & 5666 & 5898 \\
\hline
\end{tabular}

Notes: SE = Standard error. Sample weights are applied. "2009 indicator" indicates the effect of the crisis. Time-varying covariates are married, cohabiting, lives with adult other than partner, lives in rural area, and homeowner. Mediators are hours of work, real income, wealth, and anxiety or poor mental health. ${ }^{*} \mathrm{p}<.10 ;{ }^{* *} \mathrm{p}<.05 ;{ }^{* *} \mathrm{p}<.01$. 
Table 3a: Effects of Economic Crisis in Iceland on Health-Compromising Behaviors -Seemingly Unrelated Regression (SUR) and Linear Probability Estimates

\begin{tabular}{|c|c|c|c|c|c|c|}
\hline & Smoking & Heavy Drinking & $\begin{array}{l}\text { Daily Sugared } \\
\text { Soft Drink }\end{array}$ & Daily Sweets & $\begin{array}{l}\text { Weekly Fast } \\
\text { Food }\end{array}$ & $\begin{array}{l}\text { Indoor } \\
\text { Tanning }\end{array}$ \\
\hline Effects of 2009 indicator: & $\begin{array}{l}\text { Coefficient } \\
\text { (SE) }\end{array}$ & $\begin{array}{l}\text { Coefficient } \\
\text { (SE) }\end{array}$ & $\begin{array}{l}\text { Coefficient } \\
\text { (SE) }\end{array}$ & $\begin{array}{l}\text { Coefficient } \\
\text { (SE) }\end{array}$ & $\begin{array}{l}\text { Coefficient } \\
\text { (SE) }\end{array}$ & $\begin{array}{l}\text { Coefficient } \\
\text { (SE) }\end{array}$ \\
\hline \multicolumn{7}{|l|}{ SUR } \\
\hline $\begin{array}{l}\text { With basic covariates } \\
\text { (see note below) }\end{array}$ & $\begin{array}{c}-.030 * * \\
(.013)\end{array}$ & $\begin{array}{l}.025^{*} \\
(.014)\end{array}$ & $\begin{array}{l}-.013 \\
(.010)\end{array}$ & $\begin{array}{c}-.027 * * * \\
(.009)\end{array}$ & $\begin{array}{c}-.051 * * * \\
(.015)\end{array}$ & $\begin{array}{c}-.038 * * * \\
(.012)\end{array}$ \\
\hline $\begin{array}{l}\text { With basic and time-varying } \\
\text { covariates }\end{array}$ & $\begin{array}{c}-.028 * * \\
(.013)\end{array}$ & $\begin{array}{l}-.025^{*} \\
(.013)\end{array}$ & $\begin{array}{l}-.012 \\
(.010)\end{array}$ & $\begin{array}{c}-.027 * * * \\
(.009)\end{array}$ & $\begin{array}{c}-.049 * * * \\
(.014)\end{array}$ & $\begin{array}{c}-.037 * * * \\
(.012)\end{array}$ \\
\hline $\begin{array}{l}\text { With basic covariates, time - } \\
\text { varying covariates, and } \\
\text { mediators }\end{array}$ & $\begin{array}{c}-.035 * * * \\
(.014)\end{array}$ & $\begin{array}{l}-.016 \\
(.014)\end{array}$ & $\begin{array}{l}-.014 \\
(.010)\end{array}$ & $\begin{array}{c}-.031 * * * \\
(.010)\end{array}$ & $\begin{array}{c}-.036 * * \\
(.015)\end{array}$ & $\begin{array}{c}-.031 * * \\
(.013)\end{array}$ \\
\hline \multicolumn{7}{|l|}{ Linear probability } \\
\hline $\begin{array}{l}\text { With basic covariates } \\
\text { (see note below) }\end{array}$ & $\begin{array}{c}-.030 * * \\
(.013) \\
\end{array}$ & $\begin{array}{l}-.025^{*} \\
(.014) \\
\end{array}$ & $\begin{array}{l}-.013 \\
(.010) \\
\end{array}$ & $\begin{array}{c}-.027 * * * \\
(.009) \\
\end{array}$ & $\begin{array}{c}-.051 * * * \\
(.015) \\
\end{array}$ & $\begin{array}{c}-.038 * * * \\
(.012) \\
\end{array}$ \\
\hline $\begin{array}{l}\text { With basic and time-varying } \\
\text { covariates }\end{array}$ & $\begin{array}{c}.028^{* *} \\
(.013) \\
\end{array}$ & $\begin{array}{l}.025^{*} \\
(.013) \\
\end{array}$ & $\begin{array}{l}-.012 \\
(.010) \\
\end{array}$ & $\begin{array}{c}-.027 * * * \\
(.009) \\
\end{array}$ & $\begin{array}{c}-.049 * * * \\
(.015)\end{array}$ & $\begin{array}{c}-.037 * * * \\
(.012) \\
\end{array}$ \\
\hline $\begin{array}{l}\text { With basic covariates, time - } \\
\text { varying covariates, and } \\
\text { mediators }\end{array}$ & $\begin{array}{c}-.035 * * * \\
(.008)\end{array}$ & $\begin{array}{l}-.016 \\
(.011)\end{array}$ & $\begin{array}{l}-.014^{*} \\
(.007)\end{array}$ & $\begin{array}{c}-.0319 * * * \\
(.007)\end{array}$ & $\begin{array}{c}-.036 * * * \\
(.012)\end{array}$ & $\begin{array}{c}-.031^{* * *} \\
(.009)\end{array}$ \\
\hline $\mathbf{N}$ & 4524 & 4524 & 4524 & 4524 & 4524 & 4524 \\
\hline
\end{tabular}

Notes: SE = Standard error. Sample weights are applied. "2009 indicator" indicates the effect of the crisis. Basic covariates = age, age squared, gender, and education (high school, some college, college degree). Time-varying covariates are married, cohabiting, lives with adult other than partner, lives in rural area, and homeowner. Mediators are hours of work, real income, wealth, and anxiety or poor mental health. * $p<.10$; $* * p<.05 ; * * * p<.01$. 
Table 3b: Effects of Economic Crisis in Iceland on Health-Promoting Behaviors -Seemingly Unrelated Regression (SUR) and Linear Probability Estimates

\begin{tabular}{|c|c|c|c|c|c|}
\hline & $\begin{array}{l}\text { Daily } \\
\text { Fruit }\end{array}$ & $\begin{array}{c}\text { Daily } \\
\text { Vegetable }\end{array}$ & $\begin{array}{l}\text { Daily } \\
\text { Fish Oil }\end{array}$ & $\begin{array}{l}\text { Daily Vitamins/ } \\
\text { Supplements }\end{array}$ & $\begin{array}{l}\text { Recommended } \\
\text { Sleep }\end{array}$ \\
\hline Effects of 2009 indicator: & $\begin{array}{l}\text { Coefficient } \\
\text { (SE) }\end{array}$ & $\begin{array}{l}\text { Coefficient } \\
\text { (SE) }\end{array}$ & $\begin{array}{l}\text { Coefficient } \\
\text { (SE) }\end{array}$ & $\begin{array}{l}\text { Coefficient } \\
\text { (SE) }\end{array}$ & $\begin{array}{l}\text { Coefficient } \\
\text { (SE) }\end{array}$ \\
\hline \multicolumn{6}{|l|}{ SUR } \\
\hline $\begin{array}{l}\text { With basic covariates } \\
\text { (see note below) }\end{array}$ & $\begin{array}{l}-.019 \\
(.015)\end{array}$ & $\begin{array}{c}-.030 * * \\
(.014)\end{array}$ & $\begin{array}{l}.030 * * \\
(.015)\end{array}$ & $\begin{array}{l}-.013 \\
(.010)\end{array}$ & $\begin{array}{l}.033^{* *} \\
(.014)\end{array}$ \\
\hline $\begin{array}{l}\text { With basic and time-varying } \\
\text { covariates }\end{array}$ & $\begin{array}{l}-.021 \\
(.015)\end{array}$ & $\begin{array}{c}-.031 * * \\
(.014)\end{array}$ & $\begin{array}{l}.031^{* *} \\
(.015)\end{array}$ & $\begin{array}{l}-.013 \\
(.010)\end{array}$ & $\begin{array}{l}.033^{* *} \\
(.014)\end{array}$ \\
\hline $\begin{array}{l}\text { With basic covariates, time - } \\
\text { varying covariates, and mediators }\end{array}$ & $\begin{array}{l}-.024 \\
(.016)\end{array}$ & $\begin{array}{c}-.032^{* *} \\
(.015)\end{array}$ & $\begin{array}{c}.023 \\
(.016)\end{array}$ & $\begin{array}{l}-.007 \\
(.010)\end{array}$ & $\begin{array}{c}.044 * * * \\
(.015)\end{array}$ \\
\hline \multicolumn{6}{|l|}{ Linear probability } \\
\hline $\begin{array}{l}\text { With basic covariates } \\
\text { (see note below) }\end{array}$ & $\begin{array}{l}-.019 \\
(.015)\end{array}$ & $\begin{array}{c}-.030^{* *} \\
(.014)\end{array}$ & $\begin{array}{l}.030 * * \\
(.015)\end{array}$ & $\begin{array}{l}-.013 \\
(.010)\end{array}$ & $\begin{array}{l}.033^{* *} \\
(.014)\end{array}$ \\
\hline $\begin{array}{l}\text { With basic and time-varying } \\
\text { covariates }\end{array}$ & $\begin{array}{l}-.021 \\
(.015)\end{array}$ & $\begin{array}{c}-.031 * * \\
(.014)\end{array}$ & $\begin{array}{l}.031^{* *} \\
(.015)\end{array}$ & $\begin{array}{l}-.013 \\
(.010)\end{array}$ & $\begin{array}{l}.033^{* *} \\
(.014)\end{array}$ \\
\hline $\begin{array}{l}\text { With basic covariates, time - } \\
\text { varying covariates, and mediators }\end{array}$ & $\begin{array}{l}.024^{*} \\
(.012) \\
\end{array}$ & $\begin{array}{c}.032 * * * \\
(.012) \\
\end{array}$ & $\begin{array}{l}.023^{*} \\
(.012) \\
\end{array}$ & $\begin{array}{l}-.007 \\
(.009) \\
\end{array}$ & $\begin{array}{c}.044^{* * *} \\
(.012)\end{array}$ \\
\hline $\mathbf{N}$ & 4524 & 4524 & 4524 & 4524 & 4524 \\
\hline
\end{tabular}

Notes: SE = Standard error. Sample weights are applied. "2009 indicator" indicates the effect of the crisis. Basic covariates = age, age squared, gender, and education (high school, some college, college degree). Time-varying covariates are married, cohabiting, lives with adult other than partner, lives in rural area, and homeowner. Mediators are hours of work, real income, wealth, and anxiety or poor mental health. ${ }^{*} p<.10$; $* * p<.05 ; * * * p<.01$. 
Table 4a: Effects of Economic Crisis in Iceland on Health-Compromising Behaviors -Fixed Effects Models for Subsample Aged 25-64 Years

\begin{tabular}{|c|c|c|c|c|c|c|}
\hline & Smoking & $\begin{array}{l}\text { Heavy } \\
\text { Drinking }\end{array}$ & $\begin{array}{l}\text { Daily Sugared } \\
\text { Soft Drink }\end{array}$ & $\begin{array}{c}\text { Daily } \\
\text { Sweets }\end{array}$ & $\begin{array}{l}\text { Weekly Fast } \\
\text { Food }\end{array}$ & $\begin{array}{l}\text { Indoor } \\
\text { Tanning }\end{array}$ \\
\hline Effects of 2009 indicator: & $\begin{array}{l}\text { Coefficient } \\
\text { (SE) }\end{array}$ & $\begin{array}{l}\text { Coefficient } \\
\text { (SE) }\end{array}$ & $\begin{array}{l}\text { Coefficient } \\
\text { (SE) }\end{array}$ & $\begin{array}{l}\text { Coefficient } \\
\text { (SE) }\end{array}$ & $\begin{array}{l}\text { Coefficient } \\
\text { (SE) }\end{array}$ & $\begin{array}{l}\text { Coefficient } \\
\text { (SE) }\end{array}$ \\
\hline With no covariates & $\begin{array}{c}.038 * * * \\
(.007)\end{array}$ & $\begin{array}{c}-.026 * * * \\
(.009)\end{array}$ & $\begin{array}{c}-.017 * * * \\
(.006)\end{array}$ & $\begin{array}{c}-.027^{* * *} \\
(.007)\end{array}$ & $\begin{array}{c}-.067 * * * \\
(.010)\end{array}$ & $\begin{array}{c}-.043 * * * \\
(.008)\end{array}$ \\
\hline With time-varying covariates & $\begin{array}{c}-.038 * * * \\
(.007)\end{array}$ & $\begin{array}{c}-.026 * * * \\
(.009)\end{array}$ & $\begin{array}{c}-.017^{* * *} \\
(.006)\end{array}$ & $\begin{array}{c}-.026 * * * \\
(.007)\end{array}$ & $\begin{array}{c}-.066 * * * \\
(.010)\end{array}$ & $\begin{array}{c}-.043^{* * *} \\
(.008)\end{array}$ \\
\hline $\begin{array}{l}\text { With time-varying covariates plus } \\
\text { mediators }\end{array}$ & $\begin{array}{c}-.037 * * * \\
(.008)\end{array}$ & $\begin{array}{l}-.018^{*} \\
(.011)\end{array}$ & $\begin{array}{c}-.013 * * \\
(.007)\end{array}$ & $\begin{array}{l}-.023 * * \\
(.008)\end{array}$ & $\begin{array}{c}-.061 * * * \\
(.012)\end{array}$ & $\begin{array}{c}-.039 * * * \\
(.009)\end{array}$ \\
\hline $\mathbf{N}$ & $N=4230$ & $N=4222$ & $N=4230$ & $\mathrm{~N}=4214$ & $N=4248$ & $N=4042$ \\
\hline
\end{tabular}

Notes: SE = Standard error. Sample weights are applied. "2009 indicator" indicates the effect of the crisis. Time-varying covariates are married, cohabiting, lives with adult other than partner, lives in rural area, and homeowner. Mediators are hours of work, real income, wealth, and anxiety or poor mental health. ${ }^{*} p<.10 ;{ }^{* *} p<.05 ; * * *<.01$. 
Table 4b: Effects of Economic Crisis in Iceland on Health-Promoting Behaviors-Fixed Effects Models for Subsample Aged 25-64 Years

\begin{tabular}{|c|c|c|c|c|c|}
\hline & $\begin{array}{l}\text { Daily } \\
\text { Fruit }\end{array}$ & $\begin{array}{c}\text { Daily } \\
\text { Vegetable }\end{array}$ & $\begin{array}{l}\text { Daily } \\
\text { Fish Oil }\end{array}$ & $\begin{array}{l}\text { Daily Vitamins/ } \\
\text { Supplements }\end{array}$ & $\begin{array}{l}\text { Recommended } \\
\text { Sleep }\end{array}$ \\
\hline Effects of 2009 indicator: & $\begin{array}{l}\text { Coefficient } \\
\text { (SE) }\end{array}$ & $\begin{array}{l}\text { Coefficient } \\
\text { (SE) }\end{array}$ & $\begin{array}{l}\text { Coefficient } \\
\text { (SE) }\end{array}$ & $\begin{array}{l}\text { Coefficient } \\
\text { (SE) }\end{array}$ & $\begin{array}{l}\text { Coefficient } \\
\text { (SE) }\end{array}$ \\
\hline With no covariates & $\begin{array}{l}-.018 \\
(.011)\end{array}$ & $\begin{array}{c}-.029 * * * \\
(.011)\end{array}$ & $\begin{array}{l}.029 * * \\
(.011)\end{array}$ & $\begin{array}{l}-.008 \\
(.009)\end{array}$ & $\begin{array}{c}.040^{* * *} \\
(.011)\end{array}$ \\
\hline With time-varying covariates & $\begin{array}{l}-.018 \\
(.012)\end{array}$ & $\begin{array}{c}-.028 * * \\
(.011)\end{array}$ & $\begin{array}{c}.030 * * * \\
(.012)\end{array}$ & $\begin{array}{l}-.010 \\
(.009)\end{array}$ & $\begin{array}{c}.040 * * * \\
(.011)\end{array}$ \\
\hline With time-varying covariates plus mediators & $\begin{array}{l}-.022^{*} \\
(.013)\end{array}$ & $\begin{array}{c}-.032 * * \\
(.013)\end{array}$ & $\begin{array}{c}.014 \\
(.013)\end{array}$ & $\begin{array}{l}.006 \\
(.010)\end{array}$ & $\begin{array}{c}.055^{* * *} \\
(.013)\end{array}$ \\
\hline $\mathbf{N}$ & $N=4242$ & $N=4260$ & $\mathrm{~N}=4200$ & $N=4102$ & $N=4208$ \\
\hline
\end{tabular}

Notes: SE = Standard error. Sample weights are applied. "2009 indicator" indicates the effect of the crisis. Time-varying covariates are married, cohabiting, lives with adult other than partner, lives in rural area, and homeowner. Mediators are hours of work, real income, wealth, and anxiety or poor mental health. ${ }^{*} p<.10 ;{ }^{* *} p<.05 ;{ }^{* *} p<.01$. 
Table 5: Price Changes and Participation Elasticities of Various Commodities in Iceland between 2007 and 2009

\begin{tabular}{|l|c|c|c|c|c|}
\hline Commodity & $\begin{array}{c}\text { Nominal Price } \\
\text { Change (\%) }\end{array}$ & $\begin{array}{c}\text { Real Price Change } \\
\mathbf{( \% )}\end{array}$ & $\begin{array}{c}\text { Participation } \\
\text { Change Net of } \\
\text { Mediators (\%) } \\
\text { (3) }\end{array}$ & $\begin{array}{c}\text { “Participation } \\
\text { Elasticity"c }\end{array}$ & $\begin{array}{c}\text { Elasticity Range } \\
\text { (10\% Confidence } \\
\text { Interval) } \\
\mathbf{( 5 )}\end{array}$ \\
\hline Tobacco & $\mathbf{( 1 )}$ & $\mathbf{( 2 )}$ & -14.5 & -1.104 & -.704 to -1.504 \\
\hline Alcohol & 40.4 & 13.1 & -7.0 & -.328 & .008 to -.665 \\
\hline Soft drinks & 48.7 & 21.4 & -13.5 & -.452 & -.067 to -.836 \\
\hline Sweets & 57.1 & 29.8 & -24.1 & -1.067 & -.489 to -1.113 \\
\hline Fast food & 49.9 & 22.6 & -12.0 & -7.080 & -.3 .916 to -10.244 \\
\hline Indoor tanning (personal services) & 29.0 & 1.7 & -16.9 & -1.492 & -.803 to -2.181 \\
\hline Fruits & 38.7 & 11.4 & -7.6 & -.118 & -.041 to -.196 \\
\hline Vegetables & 91.8 & 64.5 & -11.1 & -1.065 & -.478 to -1.651 \\
\hline Fish oil & 37.8 & 10.5 & 4.6 & -.524 & .019 to -1.067 \\
\hline Vitamins \& supplements & 18.5 & -8.8 & -0.8 & -.123 & .098 to -.345 \\
\hline Consumer Price Index (CPI) & 33.9 & 6.6 & & & \\
\end{tabular}

Notes: Price changes are calculated from November of 2007 to November of 2009. Prices for all goods except fast food, fish oil, and vitamins/ supplements were obtained from Statistics Iceland (2012). Prices for fish oil, vitamins/supplements and fast food were obtained by personal correspondence with Statistics Iceland.

${ }^{a}$ Real price change is calculated as the nominal price change minus 27.3 (the percentage increase in CPI).

${ }^{b}$ Participation change net of mediators is calculated as the effect of the 2009 indicator, net of all time-varying covariates and mediators (bottom row of Tables $2 a \&$ b) divided by the mean value of the behavior during 2007 (from Table 1).

${ }^{\mathrm{C}}$ Participation elasticity is calculated by dividing column (3) by column (2). 


\section{Figure 1: Alcohol Sales in Iceland (liters per capita)}

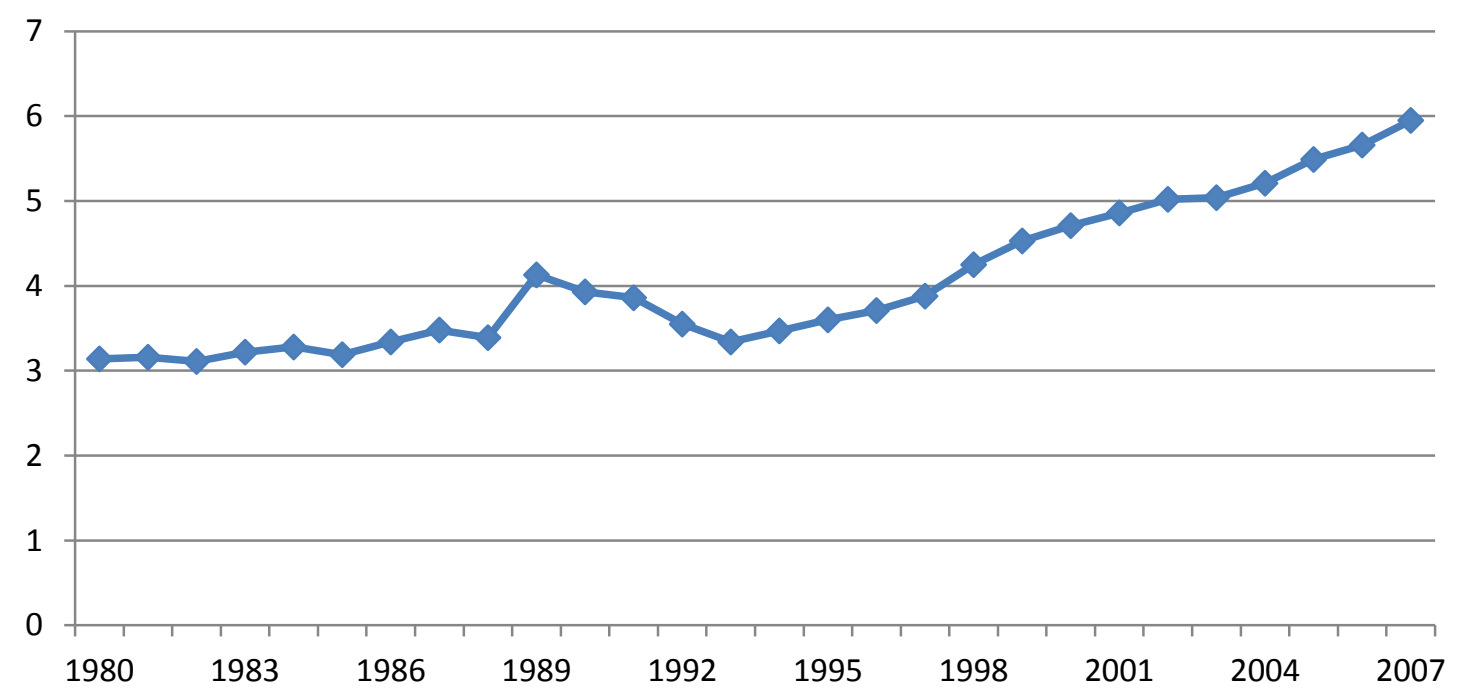

Source: The State Wine, Spirit and Tobacco Authority, Statistics Iceland (2012). Retrieved 5 April 2012.http://www.statice.is/?PagelD=1253\&src=/temp en/Dialog/varval.asp?ma=VIS05120\%26ti=Consu mption+of+alcoholic+beverages+1980\%2D2007+++\%26path=../Database/visitolur/neysla/\%26lang=1\%2 $\underline{\text { 6units=Litres }}$

\section{Figure 2: Percent of Icelanders Who Smoke Every Day}

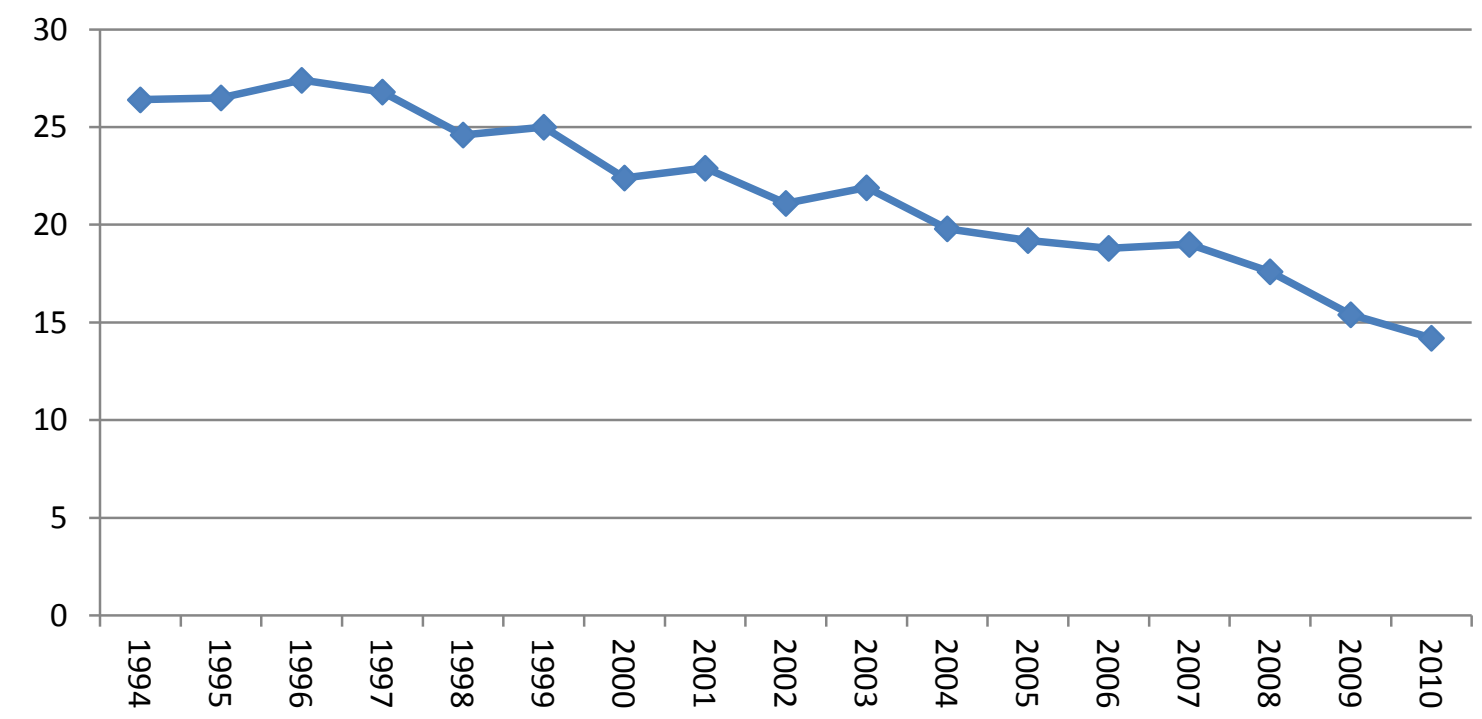

Source: Statistics Iceland (2012) Retrieved 6 April 2012.

http://www.statice.is/?PagelD=1282\&src=/temp en/Dialog/varval.asp?ma=HEl07102\%26ti=Smoking+h abits+by+sex+and+age+1994-

2010++\%26path=../Database/heilbrigdismal/afengiogreyk/\%26lang=1\%26units=Percent\%20distribution 


\section{Figure 3: Fruit Consumption in Iceland}

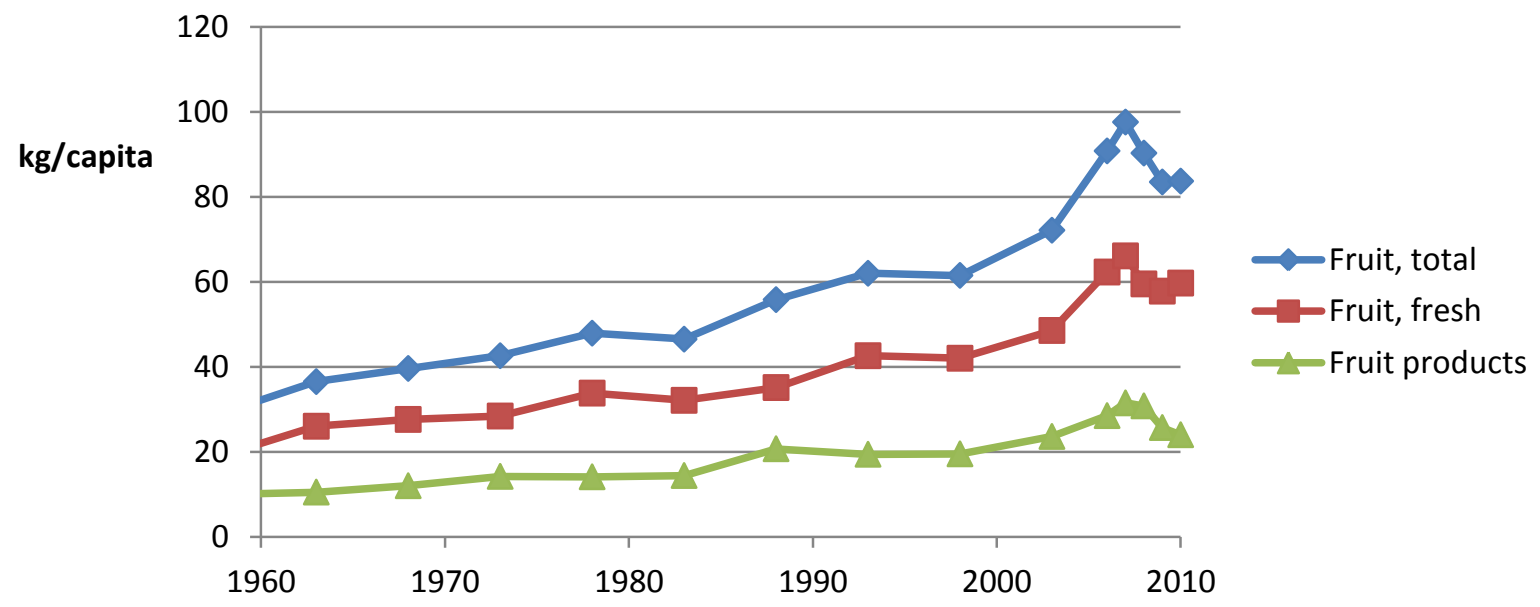

Source: The Public Health Institute of Iceland (2012a). Retrieved from:

http://www2.lydheilsustod.is/rannsoknir/matur-mataraedi-holdafar/frambod-og-sala-amatvoru/nr/2905

\section{Figure 4: Vegetable Consumption in Iceland}

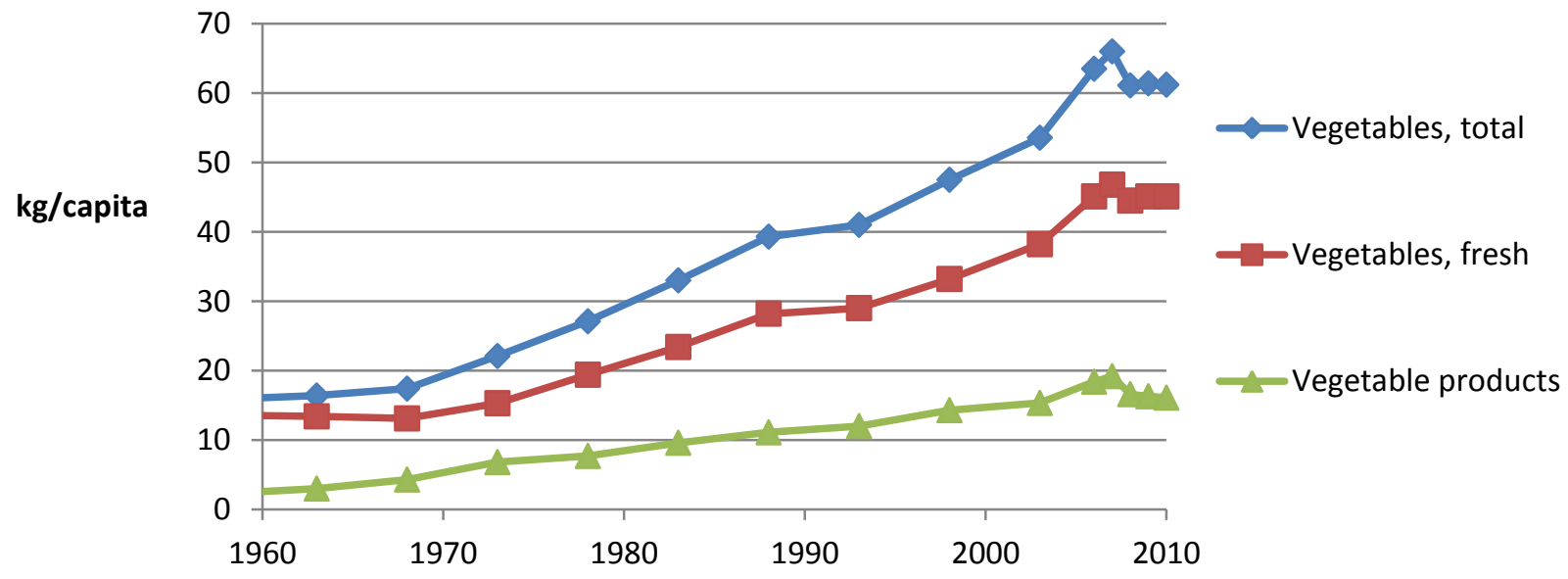

Source: The Public Health Institute of Iceland (2012a). Retrieved from:

http://www2.lydheilsustod.is/rannsoknir/matur-mataraedi-holdafar/frambod-og-sala-amatvoru/nr/2905 
Appendix Table 1a: Pooled Probit Results-Effects of Economic Crisis in Iceland on Health-Compromising Behaviors

\begin{tabular}{|c|c|c|c|c|c|c|}
\hline & Smoking & $\begin{array}{c}\text { Heavy } \\
\text { Drinking }\end{array}$ & $\begin{array}{l}\text { Daily Sugared } \\
\text { Soft Drink }\end{array}$ & $\begin{array}{c}\text { Daily } \\
\text { Sweets }\end{array}$ & $\begin{array}{l}\text { Weekly } \\
\text { Fast Food }\end{array}$ & $\begin{array}{l}\text { Indoor } \\
\text { Tanning }\end{array}$ \\
\hline & $\begin{array}{l}\text { Coefficient } \\
\qquad \begin{array}{c}\text { (SE) } \\
{[\mathrm{ME}]}\end{array}\end{array}$ & $\begin{array}{c}\text { Coefficient } \\
\text { (SE) } \\
{[\mathrm{ME}]}\end{array}$ & $\begin{array}{c}\text { Coefficient } \\
\text { (SE) } \\
{[\mathrm{ME}]}\end{array}$ & $\begin{array}{c}\text { Coefficient } \\
\text { (SE) } \\
{[\mathrm{ME}]}\end{array}$ & $\begin{array}{c}\text { Coefficient } \\
\text { (SE) } \\
{[\mathrm{ME}]}\end{array}$ & $\begin{array}{c}\text { Coefficient } \\
\text { (SE) } \\
{[\mathrm{ME}]}\end{array}$ \\
\hline 2009 indicator & $\begin{array}{c}-.124 * * * \\
(.024) \\
{[-.033]}\end{array}$ & $\begin{array}{c}-.098 * * * \\
(.031) \\
{[-.027]}\end{array}$ & $\begin{array}{c}.090 * * \\
(.043) \\
{[-.011]}\end{array}$ & $\begin{array}{c}-.173 * * * \\
(.041) \\
{[-.024]}\end{array}$ & $\begin{array}{c}-.175^{* * *} \\
(.034) \\
{[-.055]}\end{array}$ & $\begin{array}{c}-.181^{* * *} \\
(.034) \\
{[-.037]}\end{array}$ \\
\hline Age & $\begin{array}{c}.039 * * * \\
(.011) \\
{[.011]}\end{array}$ & $\begin{array}{c}-.041 * * * \\
(.011) \\
{[-.011]}\end{array}$ & $\begin{array}{c}-.046 * * * \\
(.014) \\
{[-.005]}\end{array}$ & $\begin{array}{l}-.011 \\
(.014) \\
{[-.001]}\end{array}$ & $\begin{array}{c}-.045 * * * \\
(.011) \\
{[-.014]}\end{array}$ & $\begin{array}{c}-.026 * * \\
(.013) \\
{[-.005]}\end{array}$ \\
\hline Age squared & $\begin{array}{c}-.001 * * * \\
(.0001) \\
{[-.0001]}\end{array}$ & $\begin{array}{c}.0003 * * * \\
(.0001) \\
{[.000]}\end{array}$ & $\begin{array}{c}.0002 \\
(.0002) \\
{[.000]}\end{array}$ & $\begin{array}{c}-.000 \\
(.0001) \\
{[-.000]}\end{array}$ & $\begin{array}{c}.000 \\
(.0001) \\
{[.000]}\end{array}$ & $\begin{array}{l}-.000 \\
(.000) \\
{[-.000]} \\
\end{array}$ \\
\hline Male & $\begin{array}{l}-.059 \\
(.061) \\
{[.016]}\end{array}$ & $\begin{array}{c}.700 * * * \\
(.059) \\
{[.190]}\end{array}$ & $\begin{array}{c}.376 * * * \\
(.080) \\
{[.044]}\end{array}$ & $\begin{array}{c}-.018 \\
(.073) \\
{[-.002]}\end{array}$ & $\begin{array}{c}.544 * * * \\
(.058) \\
{[.170]}\end{array}$ & $\begin{array}{c}-.439 * * * \\
(.067) \\
{[-.090]}\end{array}$ \\
\hline High school or less & $\begin{array}{c}.568 * * * \\
(.109) \\
{[.170]}\end{array}$ & $\begin{array}{c}.045 \\
(.103) \\
{[.012]}\end{array}$ & $\begin{array}{l}.275^{*} \\
(.141) \\
{[.036]}\end{array}$ & $\begin{array}{l}-.156 \\
(.130) \\
{[-.021]}\end{array}$ & $\begin{array}{c}-.073 \\
(.101) \\
{[-.023]}\end{array}$ & $\begin{array}{c}.507^{* * *} \\
(.131) \\
{[.120]}\end{array}$ \\
\hline Some college & $\begin{array}{c}.284 * * * \\
(.108) \\
{[.078]}\end{array}$ & $\begin{array}{c}.005 \\
(.100) \\
{[.001]}\end{array}$ & $\begin{array}{c}.047 \\
(.143) \\
{[.006]}\end{array}$ & $\begin{array}{l}-.046 \\
(.124) \\
{[-.006]}\end{array}$ & $\begin{array}{c}.049 \\
(.097) \\
{[.016]}\end{array}$ & $\begin{array}{c}.361 * * * \\
(.127) \\
{[.078]}\end{array}$ \\
\hline Undergraduate degree & $\begin{array}{c}.032 \\
(.118) \\
{[.009]}\end{array}$ & $\begin{array}{l}-.068 \\
(.107) \\
{[-.018]}\end{array}$ & $\begin{array}{l}.265^{*} \\
(.159) \\
{[-.028]}\end{array}$ & $\begin{array}{c}.015 \\
(.128) \\
{[.002]}\end{array}$ & $\begin{array}{c}.044 \\
(.102) \\
{[.014]}\end{array}$ & $\begin{array}{c}.118 \\
(.130) \\
{[.025]}\end{array}$ \\
\hline $\mathbf{N}$ & $N=5628$ & $N=5634$ & $N=5682$ & $N=5666$ & $N=5722$ & $N=5422$ \\
\hline
\end{tabular}

Notes: SE = Standard error. Sample weights are applied. "2009 indicator" indicates the effect of the crisis. ${ }^{*} p<.10 ;{ }^{* *} p<.05 ;{ }^{* *} p<.01$. 
Appendix Table 1b: Pooled Probit Results-Effects of Economic Crisis in Iceland on Health-Promoting Behaviors

\begin{tabular}{|c|c|c|c|c|c|}
\hline & $\begin{array}{l}\text { Daily } \\
\text { Fruit }\end{array}$ & $\begin{array}{c}\text { Daily } \\
\text { Vegetable }\end{array}$ & $\begin{array}{c}\text { Daily } \\
\text { Fish Oil }\end{array}$ & $\begin{array}{l}\text { Daily Vitamins/ } \\
\text { Supplements }\end{array}$ & $\begin{array}{l}\text { Recommended } \\
\text { Sleep }\end{array}$ \\
\hline & $\begin{array}{c}\text { Coefficient } \\
\text { (SE) } \\
{[\mathrm{ME}]}\end{array}$ & $\begin{array}{c}\text { Coefficient } \\
\text { (SE) } \\
{[\mathrm{ME}]}\end{array}$ & $\begin{array}{c}\text { Coefficient } \\
\qquad \begin{array}{c}\text { (SE) } \\
{[\mathrm{ME}]}\end{array}\end{array}$ & $\begin{array}{c}\text { Coefficient } \\
\text { (SE) } \\
{[\mathrm{ME}]}\end{array}$ & $\begin{array}{c}\text { Coefficient } \\
\text { (SE) } \\
{[\mathrm{ME}]}\end{array}$ \\
\hline 2009 indicator & $\begin{array}{c}.059 * * \\
(.029) \\
{[-.022]}\end{array}$ & $\begin{array}{c}.100 * * * \\
(.032) \\
{[-.032]}\end{array}$ & $\begin{array}{c}.080 * * * \\
(.028) \\
{[.031]}\end{array}$ & $\begin{array}{c}-.062 \\
(.039) \\
{[-.012]}\end{array}$ & $\begin{array}{c}.119 * * * \\
(031) \\
{[.038]}\end{array}$ \\
\hline Age & $\begin{array}{l}.016^{*} \\
(.009) \\
{[.006]}\end{array}$ & $\begin{array}{c}.028 * * * \\
(.010) \\
{[.009]}\end{array}$ & $\begin{array}{c}.007 \\
(.009) \\
{[.003]}\end{array}$ & $\begin{array}{c}-.025 * * \\
(.012) \\
{[-.005]}\end{array}$ & $\begin{array}{c}-.004 * * \\
(.009) \\
{[-.001]}\end{array}$ \\
\hline Age squared & $\begin{array}{c}-.000 \\
(.000) \\
{[-.000]}\end{array}$ & $\begin{array}{c}-.0002 * \\
(.0001) \\
{[-.0001]}\end{array}$ & $\begin{array}{c}.0002 * * \\
(.000) \\
{[.0001]}\end{array}$ & $\begin{array}{c}.0001 \\
(.0001) \\
{[.000]}\end{array}$ & $\begin{array}{c}.000 \\
(.000) \\
{[.000]}\end{array}$ \\
\hline Male & $\begin{array}{c}-.640 * * * \\
(.050) \\
{[-.234]}\end{array}$ & $\begin{array}{c}-.476 * * * \\
(.052) \\
{[-.154]}\end{array}$ & $\begin{array}{c}-.153^{* * *} \\
(.049) \\
{[-.059]}\end{array}$ & $\begin{array}{c}.540 * * * \\
(.007) \\
{[.104]}\end{array}$ & $\begin{array}{l}-.077 \\
(.050) \\
{[.024]}\end{array}$ \\
\hline High school or less & $\begin{array}{c}-.276 * * * \\
(.084) \\
{[-.099]}\end{array}$ & $\begin{array}{c}-.423 * * * \\
(.087) \\
{[-.128]}\end{array}$ & $\begin{array}{c}-.302 * * * \\
(.086) \\
{[-.112]}\end{array}$ & $\begin{array}{l}-.007 \\
(.110) \\
{[-.001]}\end{array}$ & $\begin{array}{c}-.291 * * * \\
(.089) \\
{[-.097]}\end{array}$ \\
\hline Some college & $\begin{array}{l}-.146^{*} \\
(.082) \\
{[-.054]} \\
\end{array}$ & $\begin{array}{c}.208 * * \\
(.085) \\
{[-.067]} \\
\end{array}$ & $\begin{array}{c}-.170 * * \\
(.083) \\
{[-.064]} \\
\end{array}$ & $\begin{array}{l}-.032 \\
(.101) \\
{[-.006]} \\
\end{array}$ & $\begin{array}{c}-.189 * * \\
(.088) \\
{[-.061]} \\
\end{array}$ \\
\hline Undergraduate degree & $\begin{array}{l}-.104 \\
(.087) \\
{[-.038]}\end{array}$ & $\begin{array}{c}.023 \\
(.088) \\
{[.007]}\end{array}$ & $\begin{array}{l}-.116 \\
(.088) \\
{[-.044]}\end{array}$ & $\begin{array}{l}-.136 \\
(.107) \\
{[-.027]}\end{array}$ & $\begin{array}{l}-.008 \\
(.094) \\
{[-.002]}\end{array}$ \\
\hline $\mathbf{N}$ & $N=5706$ & $N=5736$ & $\mathrm{~N}=5652$ & $\mathrm{~N}=5456$ & $\mathrm{~N}=5680$ \\
\hline
\end{tabular}

Notes: SE = Standard error. Sample weights are applied. "2009 indicator" indicates the effect of the crisis. ${ }^{*} p<.10 ;{ }^{* * p<.05 ;}{ }^{* * *} p<.01$. 
Appendix Table 2: Effects of Economic Crisis in Iceland on Hours of Work, Real Household Income, Loss of Wealth, and Anxiety or Poor Mental Health-Fixed Effects Models

\begin{tabular}{|c|c|c|c|c|c|c|c|c|}
\hline & \multicolumn{2}{|c|}{ Hours of Work*.10 } & \multicolumn{2}{|c|}{ Real Household Income } & \multicolumn{2}{|c|}{ Loss of Wealth } & \multicolumn{2}{|c|}{ Anxiety or Poor Mental Heath } \\
\hline & $\begin{array}{c}\text { Coefficient } \\
\text { (SE) }\end{array}$ & $\begin{array}{c}\text { Coefficient } \\
\text { (SE) }\end{array}$ & $\begin{array}{c}\text { Coefficient } \\
\text { (SE) }\end{array}$ & $\begin{array}{c}\text { Coefficient } \\
\text { (SE) }\end{array}$ & $\begin{array}{c}\text { Coefficient } \\
\text { (SE) }\end{array}$ & $\begin{array}{c}\text { Coefficient } \\
\text { (SE) }\end{array}$ & $\begin{array}{l}\text { Coefficient } \\
\text { (SE) }\end{array}$ & $\begin{array}{c}\text { Coefficient } \\
\text { (SE) }\end{array}$ \\
\hline 2009 indicator & $\begin{array}{c}-.267 * * * \\
(.043)\end{array}$ & $\begin{array}{c}-.275^{* * *} \\
(.043)\end{array}$ & $\begin{array}{c}-1.665^{* * *} \\
(.078)\end{array}$ & $\begin{array}{c}-1.672^{* * *} \\
(.076)\end{array}$ & $\begin{array}{c}2.037^{* * *} \\
(.130)\end{array}$ & $\begin{array}{c}2.043^{* * *} \\
(.129)\end{array}$ & $\begin{array}{c}.031 * * * \\
(.010)\end{array}$ & $\begin{array}{c}.031 * * * \\
(.010)\end{array}$ \\
\hline $\begin{array}{l}\text { Time-varying } \\
\text { covariates }\end{array}$ & No & Yes & No & Yes & No & Yes & No & Yes \\
\hline $\mathbf{N}$ & 6052 & 6052 & 6052 & 6052 & 6052 & 6052 & 6052 & 6052 \\
\hline
\end{tabular}

Notes: SE = Standard error. Sample weights are applied. "2009 indicator" indicates the effect of the crisis. Time-varying covariates are married, cohabiting, lives with adult other than partner, lives in rural area, and homeowner. ${ }^{*} p<.10 ;{ }^{* *} p<.05 ;{ }^{* * *} p<.01$. 
Appendix Table 3a: Effects of Economic Crisis in Iceland on Health-Compromising Behaviors-Fixed Effects Models for Men

\begin{tabular}{|c|c|c|c|c|c|c|}
\hline & Smoking & $\begin{array}{c}\text { Heavy } \\
\text { Drinking }\end{array}$ & $\begin{array}{l}\text { Daily Sugared } \\
\text { Soft Drink }\end{array}$ & $\begin{array}{c}\text { Daily } \\
\text { Sweets }\end{array}$ & $\begin{array}{l}\text { Weekly } \\
\text { Fast Food }\end{array}$ & $\begin{array}{l}\text { Indoor } \\
\text { Tanning }\end{array}$ \\
\hline Effects of 2009 indicator: & $\begin{array}{c}\text { Coefficient } \\
\text { (SE) }\end{array}$ & $\begin{array}{c}\text { Coefficient } \\
\text { (SE) }\end{array}$ & $\begin{array}{l}\text { Coefficient } \\
\text { (SE) }\end{array}$ & $\begin{array}{l}\text { Coefficient } \\
\text { (SE) }\end{array}$ & $\begin{array}{l}\text { Coefficient } \\
\text { (SE) }\end{array}$ & $\begin{array}{l}\text { Coefficient } \\
\text { (SE) }\end{array}$ \\
\hline With no time-varying covariates & $\begin{array}{c}-.033^{* * *} \\
(.010)\end{array}$ & $\begin{array}{c}-.037^{* * *} \\
(014)\end{array}$ & $\begin{array}{c}-.022 * * \\
(010)\end{array}$ & $\begin{array}{l}-.016^{*} \\
(.009)\end{array}$ & $\begin{array}{c}-.066 * * * \\
(.014)\end{array}$ & $\begin{array}{c}-.024 * * * \\
(009)\end{array}$ \\
\hline With time-varying covariates & $\begin{array}{c}-.034^{* * *} \\
(.010)\end{array}$ & $\begin{array}{c}-.035 * * \\
(.014)\end{array}$ & $\begin{array}{c}.025^{* *} \\
(.010)\end{array}$ & $\begin{array}{c}-.018^{* *} \\
(.009)\end{array}$ & $\begin{array}{c}-.065^{* * *} \\
(.014)\end{array}$ & $\begin{array}{c}-.024 * * * \\
(.009)\end{array}$ \\
\hline $\mathbf{N}$ & 2794 & 2816 & 2836 & 2826 & 2860 & 2706 \\
\hline
\end{tabular}

Notes: SE = Standard error. Sample weights are applied. "2009 indicator" indicates the effect of the crisis. Time-varying covariates are married, cohabiting, lives with adult other than partner, lives in rural area, and homeowner. ${ }^{*} p<.10 ;{ }^{* *} p<.05 ;{ }^{* *} \mathrm{p}<.01$.

Appendix Table 3b: Effects of Economic Crisis in Iceland on Health-Promoting Behaviors-Fixed Effects Models for Men

\begin{tabular}{|c|c|c|c|c|c|}
\hline & $\begin{array}{l}\text { Daily } \\
\text { Fruit }\end{array}$ & $\begin{array}{c}\text { Daily } \\
\text { Vegetable }\end{array}$ & $\begin{array}{l}\text { Daily } \\
\text { Fish Oil }\end{array}$ & $\begin{array}{l}\text { Daily Vitamins/ } \\
\text { Supplements }\end{array}$ & $\begin{array}{l}\text { Recommended } \\
\text { Sleep }\end{array}$ \\
\hline Effects of 2009 indicator: & $\begin{array}{l}\text { Coefficient } \\
\text { (SE) }\end{array}$ & $\begin{array}{l}\text { Coefficient } \\
\text { (SE) }\end{array}$ & $\begin{array}{c}\text { Coefficient } \\
\text { (SE) }\end{array}$ & $\begin{array}{c}\text { Coefficient } \\
\text { (SE) }\end{array}$ & $\begin{array}{l}\text { Coefficient } \\
\text { (SE) }\end{array}$ \\
\hline With no time-varying covariates & $\begin{array}{l}-.011 \\
(.013)\end{array}$ & $\begin{array}{l}.025^{*} \\
(.013)\end{array}$ & $\begin{array}{c}.012 \\
(.014)\end{array}$ & $\begin{array}{l}-.009 \\
(.009)\end{array}$ & $\begin{array}{c}.065 * * * \\
(.014)\end{array}$ \\
\hline With time-varying covariates & $\begin{array}{l}-.010 \\
(.014)\end{array}$ & $\begin{array}{c}-.026^{* *} \\
(.013)\end{array}$ & $\begin{array}{c}.011 \\
(.014)\end{array}$ & $\begin{array}{l}-.011 \\
(009)\end{array}$ & $\begin{array}{c}.063 * * * \\
(.014)\end{array}$ \\
\hline $\mathbf{N}$ & 2856 & 2864 & 2846 & 2748 & 2832 \\
\hline
\end{tabular}

Notes: SE = Standard error. Sample weights are applied. "2009 indicator" indicates the effect of the crisis. Time-varying covariates are married, cohabiting, lives with adult other than partner, lives in rural area, and homeowner. ${ }^{*} p<.10 ;{ }^{* *} p<.05 ;{ }^{* * *} p<.01$. 
Appendix Table 4a: Effects of Economic Crisis in Iceland on Health-Compromising Behaviors-Fixed Effects Models for Women

\begin{tabular}{|c|c|c|c|c|c|c|}
\hline & Smoking & $\begin{array}{l}\text { Heavy } \\
\text { Drinking }\end{array}$ & $\begin{array}{c}\text { Daily Sugared } \\
\text { Soft Drink }\end{array}$ & $\begin{array}{l}\text { Daily } \\
\text { Sweets }\end{array}$ & $\begin{array}{l}\text { Weekly } \\
\text { Fast Food }\end{array}$ & $\begin{array}{l}\text { Indoor } \\
\text { Tanning }\end{array}$ \\
\hline Effects of 2009 indicator: & $\begin{array}{c}\text { Coefficient } \\
\text { (SE) }\end{array}$ & $\begin{array}{l}\text { Coefficient } \\
\text { (SE) }\end{array}$ & $\begin{array}{c}\text { Coefficient } \\
\text { (SE) }\end{array}$ & $\begin{array}{l}\text { Coefficient } \\
\text { (SE) }\end{array}$ & $\begin{array}{c}\text { Coefficient } \\
\text { (SE) }\end{array}$ & $\begin{array}{c}\text { Coefficient } \\
\text { (SE) }\end{array}$ \\
\hline With no time-varying covariates & $\begin{array}{c}-.034^{* * *} \\
(.008)\end{array}$ & $\begin{array}{l}-.013 \\
(.009)\end{array}$ & $\begin{array}{l}-.007 \\
(.006)\end{array}$ & $\begin{array}{c}-.033^{* * *} \\
(.008)\end{array}$ & $\begin{array}{c}-.031 * * * \\
(.012)\end{array}$ & $\begin{array}{c}-.050 * * * \\
(.011)\end{array}$ \\
\hline With time-varying covariates & $\begin{array}{c}-.035^{* * *} \\
(.008)\end{array}$ & $\begin{array}{l}-.015 \\
(.009)\end{array}$ & $\begin{array}{l}-.005 \\
(.006)\end{array}$ & $\begin{array}{c}-.031^{* * *} \\
(.008)\end{array}$ & $\begin{array}{c}-.031^{* * *} \\
(.012)\end{array}$ & $\begin{array}{c}.050 * * * \\
(.011)\end{array}$ \\
\hline$N$ & 3048 & 3042 & 3066 & 3062 & 3086 & 2914 \\
\hline
\end{tabular}

Notes: SE = Standard error. Sample weights are applied. "2009 indicator" indicates the effect of the crisis. Time-varying covariates are married, cohabiting, lives with adult other than partner, lives in rural area, and homeowner. ${ }^{*} p<.10 ;{ }^{* *} p<.05 ;{ }^{* *} p<.01$.

\begin{tabular}{|c|c|c|c|c|c|}
\hline & $\begin{array}{l}\text { Daily } \\
\text { Fruit }\end{array}$ & $\begin{array}{c}\text { Daily } \\
\text { Vegetable }\end{array}$ & $\begin{array}{l}\text { Daily } \\
\text { Fish Oil }\end{array}$ & $\begin{array}{l}\text { Daily Vitamins/ } \\
\text { Supplements }\end{array}$ & $\begin{array}{l}\text { Recommended } \\
\text { Sleep }\end{array}$ \\
\hline Effects of 2009 indicator: & $\begin{array}{c}\text { Coefficient } \\
\text { (SE) }\end{array}$ & $\begin{array}{c}\text { Coefficient } \\
\text { (SE) }\end{array}$ & $\begin{array}{c}\text { Coefficient } \\
\text { (SE) }\end{array}$ & $\begin{array}{l}\text { Coefficient } \\
\text { (SE) }\end{array}$ & $\begin{array}{l}\text { Coefficient } \\
\text { (SE) }\end{array}$ \\
\hline With no time-varying covariates & $\begin{array}{c}-.034 * * \\
(.015)\end{array}$ & $\begin{array}{c}-.035 * * \\
(.014)\end{array}$ & $\begin{array}{c}.041 * * * \\
(.013)\end{array}$ & $\begin{array}{l}.011 \\
(.011)\end{array}$ & $\begin{array}{c}.011 \\
(.013)\end{array}$ \\
\hline With time-varying covariates & $\begin{array}{c}-.033 * * \\
(.015)\end{array}$ & $\begin{array}{c}-.035 * * \\
(.014)\end{array}$ & $\begin{array}{c}.043^{* * *} \\
(.013)\end{array}$ & $\begin{array}{l}.012 \\
(.011)\end{array}$ & $\begin{array}{c}.010 \\
(.013)\end{array}$ \\
\hline $\mathbf{N}$ & 3076 & 3098 & 3022 & 2918 & 3066 \\
\hline
\end{tabular}

Notes: SE = Standard error. Sample weights are applied. "2009 indicator" indicates the effect of the crisis. Time-varying covariates are married, cohabiting, lives with adult other than partner, lives in rural area, and homeowner. ${ }^{*} p<.10 ; * *<.05 ;{ }^{* * *} p<.01$. 